\title{
CCL18 in the Progression of Cancer
}

\author{
Jan Korbecki ${ }^{1, * \mathbb{D}}$, Mateusz Olbromski ${ }^{1}$ and Piotr Dzięgiel ${ }^{1,2}$ (I) \\ 1 Department of Histology and Embryology, Department of Human Morphology and Embryology, \\ Wroclaw Medical University, Chałubińskiego 6a St, 50-368 Wrocław, Poland; \\ olbromski.m@gmail.com (M.O.); piotr.dziegiel@umed.wroc.pl (P.D.) \\ 2 Department of Physiotherapy, Wroclaw University School of Physical Education, \\ Ignacego Jana Paderewskiego 35 Av., 51-612 Wroclaw, Poland \\ * Correspondence: jan.korbecki@onet.eu; Tel.: +48-717-841-354
}

Received: 30 September 2020; Accepted: 24 October 2020; Published: 26 October 2020

\begin{abstract}
A neoplastic tumor consists of cancer cells that interact with each other and non-cancerous cells that support the development of the cancer. One such cell are tumor-associated macrophages (TAMs). These cells secrete many chemokines into the tumor microenvironment, including especially a large amount of CCL18. This chemokine is a marker of the M2 macrophage subset; this is the reason why an increase in the production of CCL18 is associated with the immunosuppressive nature of the tumor microenvironment and an important element of cancer immune evasion. Consequently, elevated levels of CCL18 in the serum and the tumor are connected with a worse prognosis for the patient. This paper shows the importance of CCL18 in neoplastic processes. It includes a description of the signal transduction from PITPNM3 in CCL18-dependent migration, invasion, and epithelial-to-mesenchymal transition (EMT) cancer cells. The importance of CCL18 in angiogenesis has also been described. The paper also describes the effect of CCL18 on the recruitment to the cancer niche and the functioning of cells such as TAMs, regulatory $\mathrm{T}$ cells $\left(\mathrm{T}_{\text {reg }}\right)$, cancer-associated fibroblasts (CAFs) and tumor-associated dendritic cells (TADCs). The last part of the paper describes the possibility of using CCL18 as a therapeutic target during anti-cancer therapy.
\end{abstract}

Keywords: CCL18; chemokine; PITPNM3; tumor-associated macrophages; cancer; tumor; metastasis; regulatory $\mathrm{T}$ cells

\section{Introduction}

It is estimated that in 2018 alone there were 18.1 million new cases of cancer and 9.5 million deaths worldwide [1]. This is the second group of diseases in the world in terms of the number of deaths, only after cardiovascular diseases [2]. Such a high percentage of cancer mortality is related to a diagnosis in a late stage of the disease. Equally important reasons are an insufficient knowledge about cancer progression and a long period of clinical testing of new drugs [3]. Twenty years ago, cancer cells were considered to be some kind of isolated element in the neoplastic tumor [4]. The vast majority of research during this period focused on the cancer processes inside the cancer cell. This was partly related to the level of advancement of the research methods and tools. However, this model changed over time [5], and the relationship between non-neoplastic and neoplastic cells in the tumor started to be studied [6-9]. In particular, the focus turned towards intercellular communication. One of the elements of this communication are chemokines [10]. Chemokines are a group of about 50 chemotactic cytokines. They are responsible for the recruitment of different cells to the tumor niche and for some mechanisms that cause the migration of cancer cells. However, only a few chemokines play an important role in cancer processes. One of them is C-C motif chemokine ligand (CCL)18. This chemokine is mainly produced in the tumor by tumor-associated macrophages (TAMs), and its level is higher in the tumor 
than in healthy tissue. For instance, in glioblastoma multiforme, the concentration of CCL18 is over 100 times higher than in healthy brain tissue [11,12].

CCL18 plays an important role in cancer progression. However, there are no papers available containing current information about this chemokine and its role in neoplastic processes. Hence, the aim of the present paper is to gather all the key information about the role of CCL18 in cancer.

\section{The CCL18 Gene and the CCL18 Protein}

CCL18 is a chemokine from the $\beta$-chemokine sub-family because it has a -Cys-Cys- motif at the N-terminus. The gene for this protein is located on chromosome 17q11.2, and it has three exons spread over $7.1 \mathrm{~kb}[13,14]$. It encodes a 750-nucleotide-long transcript. The open reading frame for mRNA is 267 nucleotides in length [14,15]. It encodes a polypeptide of 89 amino acid residues in length. This polypeptide contains a signal peptide that which is cleaved. For this reason, the mature CCL18 protein has a weight of 78kDa and a length of 69 amino acids [15-17] (Figure 1). The actively biological form of CCL18 can be truncated to a 68-amino-acid form without a terminal alanine at the C-terminus. CCL18 has a sequence homology of $59 \%$ with the protein and of about $50 \%$ with the cDNA for CCL3/macrophage inflammatory protein $1 \alpha$ (MIP-1 $\alpha)$ [13-15,18]. Therefore, it is postulated that the CCL18 gene arose from duplication and the subsequent fusion of two MIP-1 $\alpha$-like genes, hence its occurrence in primates but not in rodents [18]. In the late 1990s and early 2000s, CCL18 was characterized and named on the basis of organ-specific expression and synthesis by specific cell types $[14,15,18]$. As a result, four alternative names for it existed simultaneously:

- $\quad$ macrophage inflammatory protein 4 (MIP-4)

- pulmonary and activation-regulated chemokine (PARC)

- $\quad$ alternative macrophage activation-associated C-C chemokine-1 (AMAC-1)

- dendritic cell-derived C-C chemokine 1 (DCCK1)

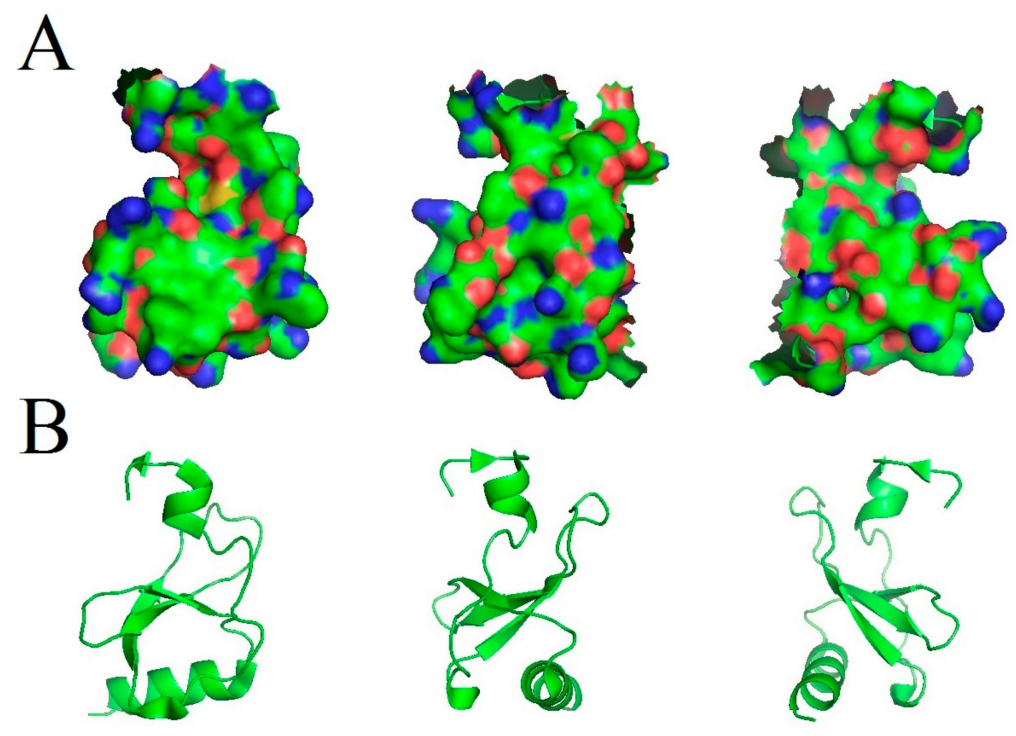

Figure 1. Modeled structure of the CCL18 protein shown under different angles. (A) Three-dimensional structure of the CCL18 protein. (B) Third-order structure of the CCL18 protein. Source: PDB ID: 4mhe; [17].

In particular, CCL18 is expressed in the lung, from which it owns one of its names $[13,14]$. In allergic asthmatics, CCL18 is produced in the lungs under the influence of allergens. It causes attracted basophil and induced basophil histamine release [19]. This process is important in the pathogenesis of asthma.

CCL18 is also produced in the germinal centers of the secondary lymphoid organs by the dendritic cells (DCs) $[13,20]$. It is a chemoattractant for $\mathrm{CD}^{-} \mathrm{IgG}^{-}$mantle zone B lymphocytes and CD45RA ${ }^{+}$ 
naïve $\mathrm{T}$ lymphocytes, but not for $\mathrm{CD} 45 \mathrm{RO}^{+}$memory $\mathrm{T}$ cells, monocytes, granulocytes, and mature DCs $[13,14,18,20,21]$, although it is a chemoattractant for 3- to 4-day-old monocytes [22]. Due to CCL18's recruitment of lymphocytes in secondary lymphoid organs, this chemokine is crucial for the initiation of the immune response [23].

CCL18 is also a macrophage M2c subset marker [24,25]. Interleukin (IL)-4 and IL-10 cause an increase in the production of CCL18 in macrophages $[15,24,25]$ However, thanks to its immunosuppressive properties, CCL18 is not only a marker but also the responsible for the properties of M2c macrophages [26]. CCL18 also plays a regulatory role in inflammatory reactions, protecting against acute pro-inflammatory responses. For this reason, phorbol 12-myristate 13-acetate (PMA) and lipopolysaccharide (LPS) also increase the expression of CCL18 in monocytes [13,22].

So far, a few receptors for CCL18 have been identified. The most important of them in neoplastic diseases is the phosphatidylinositol transfer protein 3 (PITPNM3)/PYK2 N-terminal domain-interacting receptor 1 (Nir1). This receptor is involved in migration and cell metastasis in many types of cancer [27-30]. Another receptor for the CCL18 chemokine is the C-C motif chemokine receptor (CCR)8. The activation of this receptor by CCL18 also causes the migration of tumor cells [31,32]. CCL18 can also activate CCR6 on lung fibroblasts, which is important in the development of pulmonary fibrosis [33]. The next receptor for CCL18 is the G protein-coupled estrogen receptor 1 (GPER1)/G-protein coupled receptor 30 (GPR30) [34], which is also a receptor for $17 \beta$-estradiol. The activation of this receptor by CCL18 does not result in signal transduction. Instead, it only disturbs the signal transmission from the receptor for the C-X-C motif chemokine ligand (CXCL)12/stromal-derived factor-1 (SDF-1). This reduces the chemotaxis and proliferation of tumor cells with a high expression of the CXCL12/SDF-1 chemokine [35]. It has been proven that CCL18 has this type of influence on pre-B acute lymphocytic leukemia cells [34]. Another example of receptor to which CCL18 binds is CCR3 [36,37]. Nevertheless, CCL18 exhibits an antagonistic activity in regard to this receptor, which translates into the inhibition of the infiltration of activated eosinophils, Th2 lymphocytes and basophils. CCL18 activates or has an influence on the function of many different receptors. However, only a few papers are available on the importance of receptors other than PITPNM3 in the action of CCL18. In order to better understand the role of CCL18 in neoplastic processes, additional research on the significance of the activation of the abovementoned receptors by CCL18 is required.

\section{CCL18 in Tumor Progression}

In vitro $[6,7,38,39]$ and in vivo studies [16,40-44] have shown that, in the tumor, CCL18 is produced in large amounts by TAMs, and also in smaller amounts by cancer-associated fibroblasts (CAF) [45] and cancer cells such as colon cancer cells [46], glioblastoma multiforme cells [40], non-small cell lung cancer cells [7], melanoma cells [47], and renal cell carcinoma cells [48]. The expression of CCL18 in neoplastic cells is increased by the WNT $\rightarrow \beta$-catenin pathway, as shown by in vitro experiments in the colon cancer [46] and renal cell carcinoma models [48]. This means that the effect of CCL18 in the tumor appears after TAM recruitment to the tumor niche.

The mechanism of the pro-tumor activity of CCL18 can be divided into two aspects. First, it has a direct effect on the cancer cell, in particular through the PITPNM3 receptor. As a result, the migration of neoplastic cells is induced [27]. The second aspect is the effect on non-cancerous cells, which cooperate with the neoplastic cells in the tumor. The greatest amounts of CCL18 are produced by TAMs [7,42], with CAFs producing smaller amounts [45]. This chemokine acts on these cells in an autocrine manner. For this reason, CCL18 is essential in the interdependence of TAMs and CAFs, as well as in the influence of these cells on regulatory $\mathrm{T}$ cells $\left(\mathrm{T}_{\mathrm{reg}}\right)[49,50]$ and tumor-associated dendritic cells (TADCs) [26]. 


\subsection{Effect of CCL18 on Cancer Cells}

\subsubsection{Influence of CCL18 on Cancer Cell Proliferation}

CCL18 may have an influence on the proliferation of cancer cells. However, this effect is dependent on the type of tumor. In non-small cell lung cancer cells, CCL18 reduces proliferation [51]. It also reduces the proliferation of pre-B acute lymphocytic leukemia cells [34]. This effect depends on the activation of GPER1/GPR30, which leads to the disruption of the function of CXCR4. In breast cancer [52,53], diffuse large B cell lymphoma [54], ovarian cancer [55], osteosarcoma [56], and urothelial carcinoma [57], the chemokine increases the proliferation of cancer cells. Moreover, CCL18 does not affect the proliferation of gastric cancer [58] and pancreatic ductal adenocarcinoma cells [59]. At least in osteosarcoma cells, CCL18 causes an increase in the expression of the urothelial carcinoma associated 1 (UCA1), which results in the activation of the WNT $\rightarrow \beta$-catenin pathway [56]. This in turn results in an increased proliferation and migration of these cells. It has also been shown that CCL18 can increase the expression of stem cell markers in the cells of tumors such as oral squamous cell carcinoma [60] and squamous cell carcinoma of the head and neck [61]. In the oral squamous cell carcinoma HSC-6 and CAL33 cell lines, this was associated with the activation of the mammalian target of rapamycin (mTOR) [60].

\subsubsection{CCL18 as an Inducer of EMT and Migration of Tumor Cells}

One of CCL18's receptors is PITPNM3. This receptor has been best studied in CCL18-dependent migration induction, invasion and epithelial-to-mesenchymal transition (EMT) tumor cells. PITPNM3 is important in the migration and metastasis of cells of tumors such as hepatocellular carcinoma [62], breast cancer [27,63-65], non-small cell lung cancer [30,51], oral squamous cell carcinoma [29], ovarian cancer [66], pancreatic ductal adenocarcinoma [67], prostate cancer [28], and squamous cell carcinoma of the head and neck [68].

The activation of PITPNM3 causes signal transduction through several pathways (Figure 2). Phosphorylation of the phospholipase $\mathrm{C} \gamma 1$ (PLC $\gamma 1$ ) and the protein kinase $\mathrm{C}-\zeta$ (PKC $\zeta$ ) [69] takes place, as well as an increase of the expression of the inositol 1,4,5-trisphosphate 3-kinase isoform B (IP3KB), which activates intracellular calcium signaling [69]. PITPNM3 causes signal transduction through the JAK2 $\rightarrow$ STAT3 pathway, leading to the proliferation, migration, and EMT of oral squamous cell carcinoma cells [70].

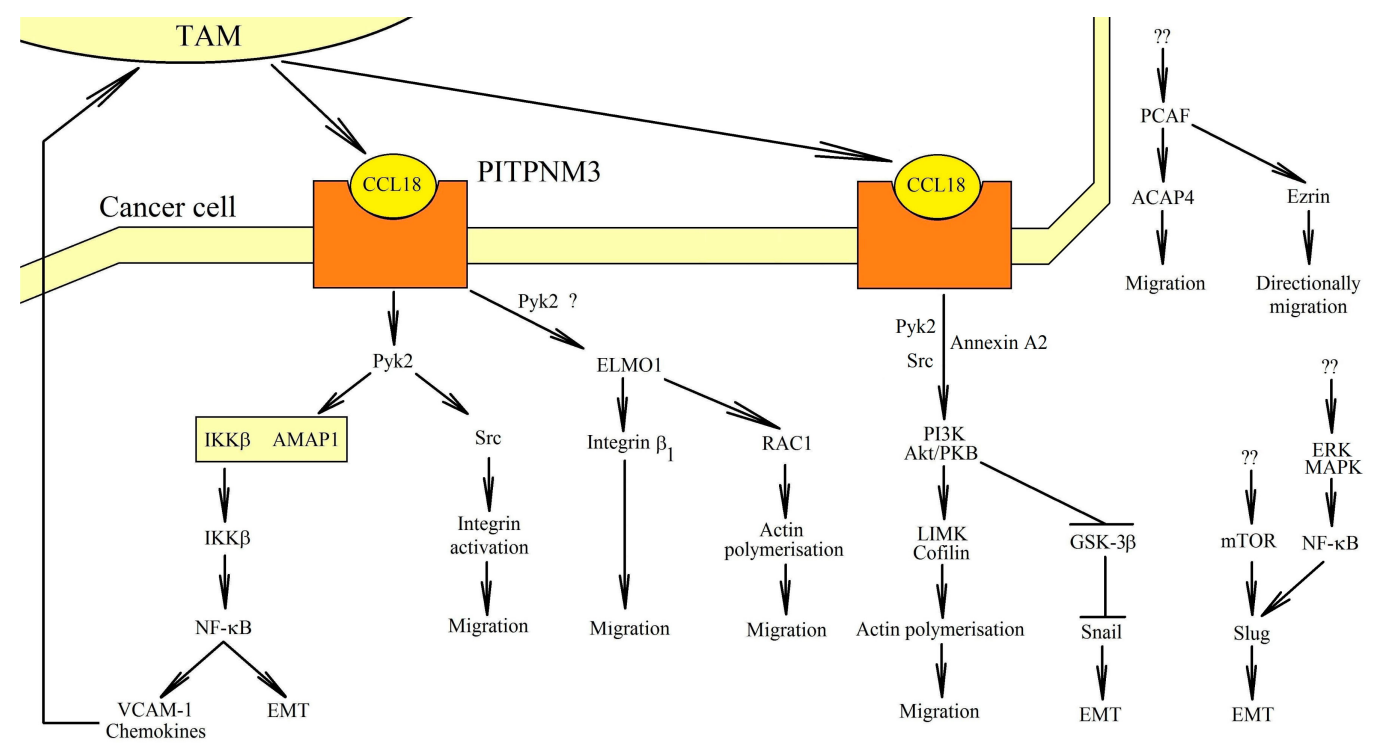

Figure 2. Role of PITPNM3 in cancer cell migration. CCL18 activates its PITPNM3 receptor. This results in signal transduction from this receptor. Pyk2 activation takes place, which leads to the activation of 
NF- $\kappa$ B. This transcription factor causes EMT. NF- $\kappa$ B also increases the expression of chemokines and VCAM-1, which cause the recruitment of TAMs in the vicinity of the tumor cell and, consequently, an even greater concentration of CCL18 in the vicinity of the PITPNM3 receptor. In addition to the NF- $\mathrm{kB}$-dependent pathway, PITPNM3 causes the activation of ELMO1, which leads to changes in actin polymerization and tumor cell migration. At the same time, with the activation of Pyk2, the PI3K $\rightarrow$ Akt/PKB pathway is activated, leading to an increase in Snail expression and then to the EMT of tumor cells. CCL18 can also activate other signaling pathways, but some of them have not yet been associated with any of the receptors. CCL18 can activate mTOR, which leads to an increase in Slug expression. This leads to the EMT of tumor cells. CCL18 also causes directional migration of breast cancer cells by increasing ezrin acetylation by PCAF.

PITPNM3 causes signal transduction through the proline-rich tyrosine kinase 2 (Pyk2) $[27,62,66]$. Pyk2 is a non-receptor protein tyrosine kinase belonging to the focal adhesion kinase (FAK) family [71]. An activated Pyk2 causes the phosphorylation of a multiple-domain Arf-GAP protein 1 (AMAP1) (other names: DDEF1 and ASAP1) [64]. This causes the dissociation of the AMAP1 complex from the inhibitor of NF- $\kappa B$ kinase $\beta$ subunit $(\mathrm{IKK} \beta)$. IKK $\beta$ is released, and then the nuclear factor $\kappa B(N F-\kappa B)$ is activated. NF- $\kappa B$ is directly responsible for the transcription of the genes responsible for EMT [72-74]. As a result, the migration and metastasis of neoplastic cells take place [62]. The activation of NF- $k B$ by CCL18 also increases the expression of metadherin (MTDH), which leads to the EMT of the cells of the squamous cell carcinoma of the head and neck [68]. However, the CCL18-dependent activation of NF- $\kappa B$ can be inhibited by IL-32 $\theta$ in breast cancer cells [75]. This is related to the interaction of IL-32 $\theta$ with protein kinase $C-\delta(P K C \delta)$, although the importance of PKC $\delta$ in the effects of CCL18 on the tumor cell still needs to be thoroughly investigated.

Activated by PITPNM3, Pyk2 can activate Src in breast cancer cells [76]. This kinase is essential in integrin $\alpha_{5} \beta_{1}$ clustering-dependent adherence. As a result, the integrin activation and migration of the cancer cells take place. The signal transmission also includes engulfment and cell motility 1 (ELMO1), which has been proven on non-small cell lung cancer cells [30]. This protein causes $\beta_{1}$ integrin phosphorylation and the activation of RAC1, which is also involved in the polymerization of actin and the migration of cancer cells.

When PITPNM3 is activated, the phosphatidylinositol-4,5-bisphosphate 3-kinase (PI3K) $\rightarrow$ Akt/protein kinase B (PKB) pathway is also activated [29,63,75]. In breast cancer cells, this is related to the activation of the Src kinase by Pyk2 [76]. Annexin A2 plays an important role in this mechanism [77]. However, it is also possible that the activation of NF- $\mathrm{BB}$ is dependent on the $\mathrm{PI} 3 \mathrm{~K} \rightarrow \mathrm{Akt} / \mathrm{PKB}$ pathway. This pathway causes the activation of NF- $\mathrm{kB}$, which produces an increase in the expression of Lin28b in breast cancer cells [78]. This leads to a reduction in the levels of miR-98 and miR-27b. On the one hand, miR-98 silences N-Ras. A reduction in the levels of miR-98 lead to the activation of the N-Ras $\rightarrow$ extracellular signal-regulated kinase (ERK) mitogen-activated protein kinase (MAPK) $\rightarrow \mathrm{PI} 3 \mathrm{~K} \rightarrow \mathrm{NF}-\mathrm{kB} \rightarrow \mathrm{Lin} 28 \mathrm{~b}$ pathway. On the other hand, miR-27b inhibits EMT in cancer cells. When miR-27b levels are reduced, EMT is induced in breast cancer cells.

The activation of Akt/PKB leads to the activation of two pathways [63]. The first one, LIN-11, Is11 and MEC-3 protein domain kinase (LIMK) $\rightarrow$ cofilin, is responsible for the polymerization of actin and, therefore, the migration of cancer cells. In the second pathway, Akt/PKB causes the

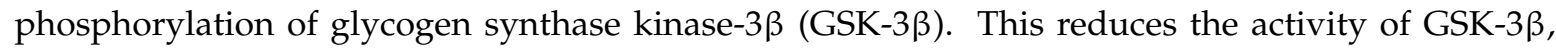
which leads to the stabilization of Snail. Snail levels increase, leading to EMT [59,63,77,79].

In breast cancer cells, CCL18 also activates the p300/CBP-associated factor (PCAF). This is the acetyltransferase that causes the acetylation of ACAP4 [80] and ezrin [81]. Acetylated ACAP4 regulates membrane cytoskeletal dynamics, which results in cell migration. In contrast, ezrin acetylation is associated with directionally persistent migration. Nevertheless, there are no data on the exact way of activation of the PCAF by CCL18. 
Additionaly, CCL18 is proved to play a crucial role in the migration and EMT processes of tumor cells by activating receptors other than PITPNM3. In particular, CCL18 promotes the EMT activation of blader cancer cells by activating CCR8 [32]. However, CCL18 may also reduce cancer cell migration by activating GPER1/GPR30, where this chemokine interferes with the action of CXCR4 on pre-B acute lymphotic leukemia cells [34]. This reduces the migration of these cells in response to CXCL12/SDF-1.

CCL18 can activate other signaling pathways, but some of them have not yet been associated with any of the receptors. In some types of cancer, CCL18 can activate mTOR. The activity of mTOR in neoplasms is often deregulated, which leads to increased proliferation, migration of cancer cells and an increase in the synthesis of nucleotides and proteins [82]. mTOR activation via CCL18 leads to cell migration in tumors such as endometrial cancer [83], ovarian cancer [55], and oral squamous cell carcinoma [60]. CCL18 seems to activate mTOR via the PI3K $\rightarrow$ Akt/PKB pathway, as shown by experiments on endometrial cancer cells [83]. The activation of mTOR leads to an increase in KIF5B expression in the cell line Ishikawa (endometrial cancer), which, in turn, leads to EMT [83]. The activation of mTOR also increases Slug expression and the induction of EMT in oral squamous cell carcinoma, as demonstrated by experiments conducted on the HSC- 6 and CAL33 cell lines [60]. However, an increase in Slug expression can occur by the activation by CCL18 of the ERK $\mathrm{MAPK} \rightarrow \mathrm{NF}-\mathrm{KB}$ cascade, which was demonstrated on MGC-803 gastric cancer cells [58].

CCL18 also causes the migration of the osteosarcoma cell lines MG63 and 143B [56]. This action is dependent on the increase in UCA1 expression by the EP300 transcription factor. As a consequence, the $\mathrm{WNT} \rightarrow \beta$-catenin pathway is activated, which results in the proliferation and migration of osteosarcoma cells.

Nonetheless, many of the aforementioned data have been obtained without the association of these pathways to a given receptor for CCL18. Therefore, in order to better understand the effect of this chemokine, research into the exact mechanism of action of CCL18 and the study of which receptor is activated by it are required. In addition to PITPNM3, other receptors are also responsible for the CCL18-dependent migration and EMT of tumor cells, for instance CCR8 in bladder cancer cells [32].

\subsubsection{Influence of microRNA in the Function of CCL18}

CCL18 expression and function is under the control of microRNAs. Particularly, CCL18 is a target gene of miR-128 [84], miR-205 [47], and miR-622 [85]. In melanoma cells, colorectal neoplasia differentially expressed (CRNDE) long non-coding RNA (lncRNA) regulates miR-205, which causes CCL18 expression to increase [47].

MicroRNAs also regulate the function of CCL18. miR-622 blocks the activation of ERK MAPK, thereby disrupting the activation of this cascade by CCL18, and thus the action of this chemokine [85]. Moreover, miR-181b decreases NF- $\mathrm{kB}$ expression, which interferes with the function of CCL18, as this transcription factor is important in the induction of migration and EMT by CCL18 [52].

CCL18 also causes changes in microRNA expression, which causes the migration of cancel cells. The activation of NF- $\mathrm{KB}$ by CCL18 results in an increase in the expression of Lin28b in breast cancer cells [78]. This leads to a reduction in the levels of miR-98 and miR-27b. MiR-98 silences $\mathrm{N}$-Ras, i.e., CCL18 causes the activation of the N-Ras $\rightarrow$ ERK MAPK $\rightarrow$ PI3K $\rightarrow$ NF- $\mathrm{kB} \rightarrow$ Lin28b pathway, which increases the activity of CCL18. On the other hand, miR-27b inhibits EMT in cancer cells. When miR-27b levels are reduced, EMT of breast cancer cells is induced.

In esophageal squamous cell carcinoma, CCL18 increases the expression of the hox transcript antisense intergenic RNA (HOTAIR) [86]. This is a lncRNA that functions as a miR-130a-5p sponge. This results in a decrease in the level of miR-130a-5p, and therefore an increase in the level of ZEB1. As a consequence, EMT of cancer cells takes place. 


\subsection{Influence of CCL18 on Tumor-Associated Cells and Tumor Microenvironment}

\subsubsection{Effect of CCL18 on Angiogenesis and Lymphangiogenesis}

In the initial stages, the intensive proliferation of neoplastic cells and tumor growth are not related to the development of blood vessels [87]. This causes hypoxia in the centre of the growing tumor, which results in significant changes in its functioning. Angiogenesis is closely related to the migration and metastasis of neoplastic cells $[88,89]$ takes place. One of the most important factors inducing angiogenesis is the vascular endothelial growth factor (VEGF), although there are also numerous other factors that induce angiogenesis in the tumor. One of them is CCL18 [50,90]. This is associated with the presence of the PITPNM3 receptor on the cells of the blood vessel walls. Studies with human umbilical vein endothelial cells (HUVECs) show that CCL18 causes the VEGF-independent migration and tube formation of these cells [90]. CCL18 also causes HUVECs EMT, which is dependent on ERK MAPK activation and the Akt/PKB $\rightarrow$ GSK-3 $\beta \rightarrow$ Snail pathway, as well as EMT of cancer cells $[59,63,77]$. At the same time, in the bladder cancer model, CCL18 causes an increase in the production of VEGF-C and matrix metalloproteinase-2 (MMP-2), which are factors involved in lymphangiogenesis [32]. This process is dependent on CCR8.

CCL18 is a hypoxia-repressed gene [91-93]. Under chronic hypoxia conditions, the expression of CCL18 is independent of the hypoxia inducible factors (HIFs) activation but dependent on the lysine-specific demethylase 6B (KDM6B)/Jumonji domain-containing protein D3 (JMJD3) activity [94]. This enzyme is a histone demethylase, which is an oxygen-dependent enzyme. A reduction in oxygen concentration causes a decrease in the activity of KDM6B/JMJD3, which results in histone methylation and thus a decrease in CCL18 expression at the transcription level.

\subsubsection{Tumor-Associated Macrophages and CCL18 in the Neoplastic Tumor}

A neoplastic tumor not only contains cancer cells. There are also tumor-associated cells that participate in the progression of the tumor. One of these cells are TAMs [95]. An increased number of these cells in the neoplastic tumor correlates with a worse prognosis for patients of multiple neoplasms [96-98]. These cells are derived from monocytes, which are recruited into the tumor niche and then differentiated into TAMs. Certain chemokines, such as the CCL2/monocyte chemoattractant protein (MCP)-1 [99], the CCL5/regulated on activation, the normally $\mathrm{T}$ cell expressed and secreted (RANTES) [100] and the CCL8/MCP-2 [101] (Figure 3) are responsible for the recruitment of TAMs. However, CCL18 is not a chemotactic agent for monocytes or macrophages $[13,14,18,20,21]$, which is why it does not affect the recruitment of TAMs into the tumor niche. Nevertheless, TAMs are responsible for the production of CCL18 in the tumor $[6,7,16,38-44]$.

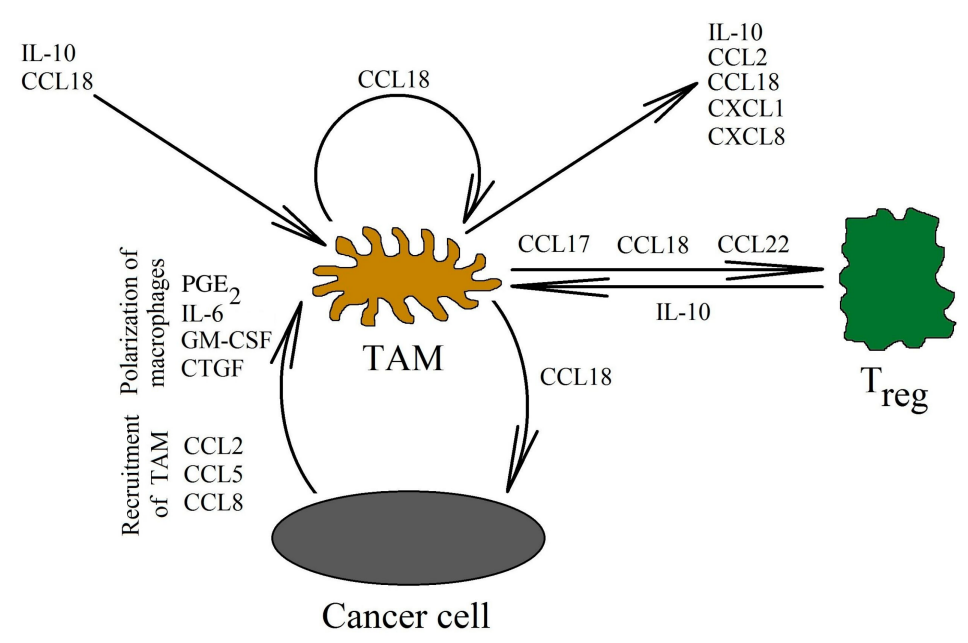

Figure 3. CCL18 as an important factor in the interaction of TAMs with cells in the neoplastic tumor. 
CCL18 is mainly produced by TAMs. These cells are recruited into the tumor niche as monocytes by different chemokines, but not by CCL18. Subsequently, monocytes undergo differentiation into TAMs by various factors from the tumor microenvironment (one of them is CCL18). Next, CCL18 expression induction takes place, which causes $\mathrm{T}_{\text {reg }}$ cells recruitment into the tumor niche. This chemokine also increases the expression of factors such as IL-10, CCL2/MCP-1, CXCL1/GRO- $\alpha$, and CXCL8/IL-8. These factors are involved in the development of the neoplastic tumor by recruiting tumor-associated cells, and they also participate in the migration of neoplastic cells and in cancer immune evasion.

TAMs in human tumors are not strictly prescribed to the M2 subset [9,42]. They show mixed M1 and M2 phenotype. Examples of factors causing the polarization of macrophages in the tumor microenvironment are IL-4 and IL-6 [102], prostaglandin $\mathrm{E}_{2}\left(\mathrm{PGE}_{2}\right)$ [103], IL-10 released by $\mathrm{T}_{\text {reg }}$ cells and the direct cell-cell interaction of these cells with macrophages [15,104], tumor acidification [105,106], extracellular matrix [107], granulocyte-macrophage colony-stimulating factor (GM-CSF) [108], connective tissue growth factor (CTGF) [109], and many others. CCL18 affects the phenotype of TAMs. In the absence of other differentiating factors, CCL18 causes the differentiation of monocytes into M2 macrophages [110]. These macrophages show the expression of the M2 polarization marker CD206, as well as the expression of cytokines that are important in the progression of cancer: IL-10, CXCL8/IL-8 and CCL2/MCP-1. CCL18 also increases the production of the CXCL1/growth related oncogene- $\alpha$ (GRO- $\alpha$ ) and IL-6 in macrophages [111]. Some of these chemokines are involved in the recruitment of cells into the tumor niche: CCL2/MCP-1 in the recruitment of TAMs [99], and CXCL1/GRO- $\alpha$ in the recruitment of neutrophils [112] and myeloid-derived suppressor cells (MDSC) [113]. These chemokines also participate in the angiogenesis and migration of cancer cells [114,115].

In vitro studies have shown that CCL18 is mainly produced by TAMs in the neoplastic tumor $[6,7,16,38-44]$. CCL18 expression in macrophages is increased by estrogen receptor $\alpha(E R \alpha)$ activation [83], IL-4 and IL-6 [102], extracellular matrix [107], IL-10 released by $\mathrm{T}_{\text {reg }}$ cells and the direct cell-cell interaction of these cells with TAMs [104], GM-CSF [108], and CTGF [109]. In contrast, CCL18 expression in macrophages is reduced by interferon- $\gamma$ (IFN- $\gamma$ ) [116,117]. In a tumor, CCL18 also indirectly influences TAMs and thus its own synthesis. NF- $\mathrm{KB}$ activated by CCL18 is equally responsible for the increase in the expression of the vascular cell adhesion molecule-1 (VCAM-1) on pancreatic ductal adenocarcinoma cells [67]. This protein causes TAMs to bind to the cancer cells. TAMs produce CCL18, increasing the production of VCAM-1 even further. Additionally, this protein increases the Warburg effect in the cancer cell. This in turn increases the secretion of lactate into the neoplastic microenvironment, which causes its acidification. This acidification induces alternative activated M2 phenotype macrophages polarization and, thus, the production of CCL18 in TAMs is further increased $[67,105,106]$. Many chemokines are also under the control of NF-KB. For this reason, the activation of this transcription factor by CCL18 causes an increase in the expression of the chemokines responsible for the recruitment of more TAMs. This leads to an increase in the production of CCL18 in the vicinity of the tumor cells [108].

\subsubsection{CCL18 and $\mathrm{T}_{\text {reg }}$ Recruitment into the Tumor Niche}

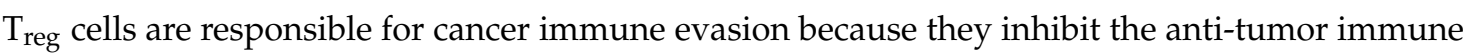
response [118]. As shown in breast cancer research studies, these cells in the tumor niche express CCR8 (receptor for CCL1/I-309) and CCR4 (receptor for CCL17/thymus and activation regulated chemokine (TARC) and CCL22/macrophage derived chemokine (MDC)) [119,120]. For this reason, chemokines such as CCL1/I-309 (in breast cancer) [121,122], CCL17/TARC, CCL22/MDC (in gastric cancer and hepatocellular carcinoma) [123,124], and CCL28/MEC (in hepatocellular carcinoma) [125] cause $\mathrm{T}_{\text {reg }}$ recruitment into the tumor niche. $\mathrm{T}_{\text {reg }}$ cells are also recruited by the CCL20/macrophage inflammatory protein $3 \alpha$ (MIP-3 $\alpha) \rightarrow$ CCR6 axis, as shown in research on colorectal cancer [126], hepatocellular carcinoma [127], and non-small-cell lung carcinoma [128] models.

CCL18, produced by TAMs, also plays an important role in $\mathrm{T}_{\text {reg }}$ recruitment $[50,116,129]$. The CCL18 chemokine recruits $\mathrm{CD} 4^{+} \mathrm{CD} 45 \mathrm{RA}^{+} \mathrm{CD} 25^{-}$naïve $\mathrm{T}$ cells into the tumor niche, and then 
they are differentiated into $T_{\text {reg }}$ cells, as shown in research studies on gastric cancer [130] and breast cancer [129]. This process is related to the recruitment of these cells via the PITPNM3 receptor [129]. Then, the differentiation of naïve $\mathrm{T}$ cells into $\mathrm{T}_{\text {reg }}$ cells takes place. Next, in the neoplastic tumor, there is a mutual interaction between TAMs and $\mathrm{T}_{\text {reg }}$ cells. On the one hand, TAMs participate in the recruitment of $\mathrm{T}_{\text {reg }}$ cells through CCL18 $[129,130]$, while on the other hand, $\mathrm{T}_{\text {reg }}$ cells increase macrophage polarization and the production of CCL18 in them [104]. This is related to the production of IL-10 by $\mathrm{T}_{\text {reg }}$ and the direct cell-cell interaction of these cells with TAMs.

CCL18 also participates in the recruitment of memory CD4 ${ }^{+} \mathrm{CD} 25^{+}$Foxp3- $\mathrm{T}$ cells $[49,131]$. These cells produce IL-4, IL-10, and the transforming growth factor $\beta 1$ (TGF- $\beta 1$ ), which are factors involved in neoplastic processes. CCL18 can also convert $\mathrm{CD} 4^{+} \mathrm{CD} 25^{-}$memory $\mathrm{T}$ cells into $\mathrm{CD} 4^{+} \mathrm{CD} 25^{+} \mathrm{Foxp}^{+}$ $\mathrm{T}_{\text {reg }}$ [132]. The recruitment of naïve T cells by CCL18 has been confirmed in tumor models $[129,130]$. However, the recruitment of memory $\mathrm{T}$ cells by this chemokine has not yet been proven in these models [49,132].

The mechanisms of $\mathrm{T}_{\text {reg }}$ recruitment into the tumor niche are not yet fully understood $[131,133]$. $\mathrm{T}_{\text {reg }}$ cells can be divided into over 20 subsets [134]. It is likely that many types of $\mathrm{T}$ cells are recruited into the tumor niche. Many chemokines involved in this process, not only CCL18, are also produced by TAMs in the neoplastic tumor $[25,42,108]$. Examples of such chemokines are CCL17/TARC and CCL22/MDC $[123,124]$. CCL18 may be involved in recruiting certain types of T cells, and it can also participate in differentiating them into $\mathrm{T}_{\text {reg }}$ cells. However, more research is required in order to better understand $\mathrm{T}_{\text {reg }}$ recruitment into the tumor niche.

\subsubsection{Tumor-Associated Dendritic Cells and CCL18}

DCs are cells involved in the normal anti-tumor immune response. Mature DCs are recruited into the tumor niche by the CCL19/MIP-3 $\beta$ and CCL21/secondary lymphoid tissue (SLC) chemokines [135]. They stimulate cytotoxic NK cells [136,137] and CD8 ${ }^{+} \mathrm{T}$ lymphocytes [138] to kill cancer cells. DCs also kill cancer cells directly [139]. On the other hand, immature DCs are recruited by CCL20/MIP-3 $\alpha[135,140]$. CCL18 also causes the chemotaxis of immature DCs, which shows that this chemokine may be involved in the direct recruitment of immature DCs into the tumor niche [141] (Figure 4). In the tumor microenvironment, these cells are differentiated into TADCs. These cells have immunosuppressive characteristics because they participate in the recruitment of $T_{\text {reg }}$ cells into the tumor niche and enhance their pro-cancer properties [142]. They also produce the heparin-binding EGF-like growth factor (HB-EGF) and amphiregulin (epidermal growth factor receptor (EGFR) ligands), thus stimulating the development of lung cancers $[143,144]$. In colon cancer, TADCs also produce CCL5/RANTES [145]. This chemokine participates in the migration of cancer cells and the recruitment of various types of cells into the tumor niche. However, the exact pro-cancer effect of TADCs is still poorly understood and requires further thorough research.

The factors influencing the formation of TADCs in the neoplastic tumor have not yet been studied in depth. However, it seems that the most important of them are PGE 2 [146], CCL18 [26], and IL-10 [147]. In the tumor, CCL18, IL-10, and PGE 2 are produced by TAMs. CCL18 can also be produced by immature DCs $[35,141,148]$. CCL18 causes the chemotaxis of immature DCs into the tumor niche [141]. At this point, CCL18 causes an increase in IL-10 expression in the differentiating DCs [26]. IL-10 then causes an increase in the expression of indoleamine 2,3-dioxygenase (IDO) [147]. The same goes for $\mathrm{PGE}_{2}$, which, from the tumor microenvironment, increases the expression of IDO in the differentiating DCs [146]. The expression of IDO in the DCs causes an increase in the number of $\mathrm{T}_{\text {reg }}$ cells [26,149-151]. The differentiation of naïve $C D 4^{+} \mathrm{T}$ cells into $\mathrm{T}_{\text {reg }}$ cells is behind this process [142]. CCL18 is also important in this process, because it is responsible for the chemotaxis of naïve CD4 $4^{+} \mathrm{T}$ cells close to TAMs and immature DCs $[20,23,130]$. 


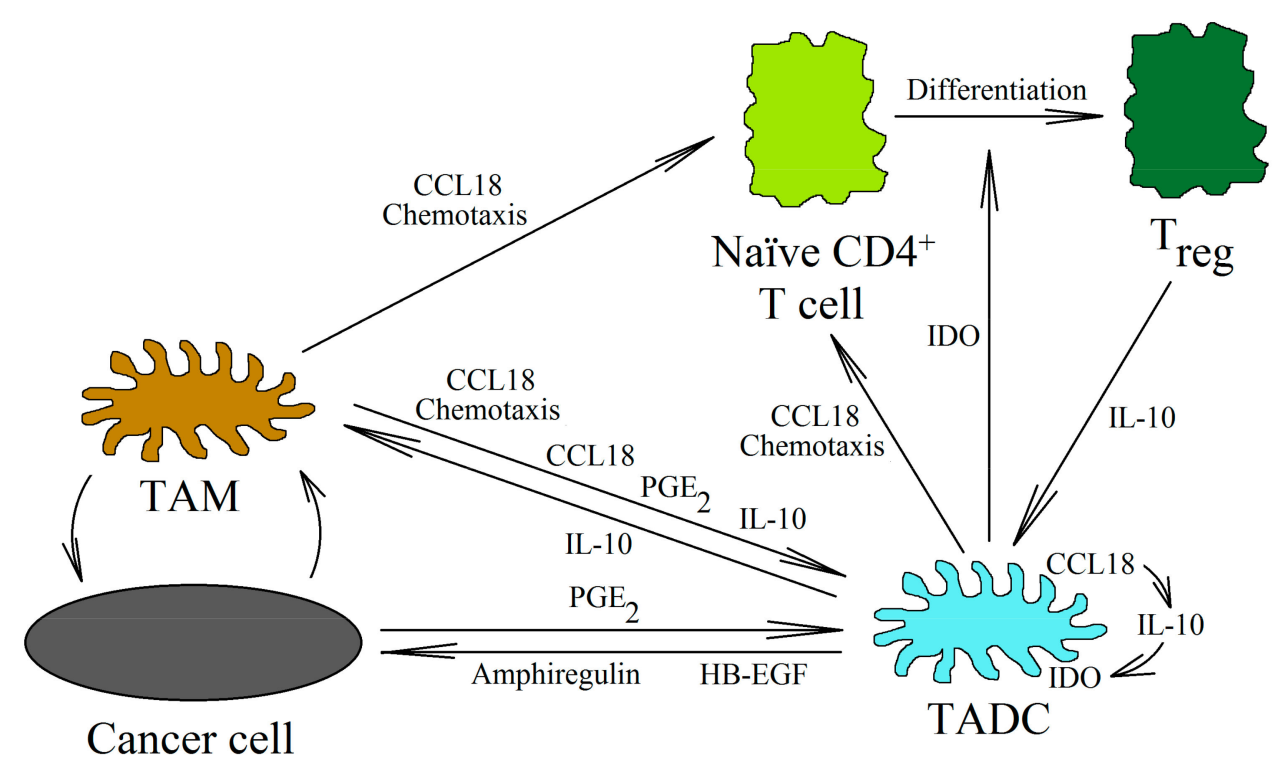

Figure 4. Tumor-associated dendritic cells in the tumor niche. Immature DCs and TAMs produce CCL18 in the tumor niche. This chemokine causes the chemotaxis and recruitment of immature DCs and naïve $\mathrm{CD}^{+}{ }^{+} \mathrm{T}$ cells into the tumor niche. Next, CCL18 causes the differentiation of immature DCs into TADCs. The production of IL-10 increases in these cells, and thus the expression of IDO is autocrinally increased. However, $\mathrm{PGE}_{2}$, produced by various cells (including TAMs and cancer cells), is also involved in this process. IDO is an enzyme that metabolizes tryptophan. The metabolites of this amino acid cause the differentiation of naïve $\mathrm{CD} 4^{+} \mathrm{T}$ cells into $\mathrm{T}_{\text {reg }}$ cells. In turn, $\mathrm{T}_{\text {reg }}$ cells produce IL-10, which enhances the functions of TADCs. In addition to their effects on $\mathrm{T}_{\text {reg }}$ cells, TADCs enhance tumor growth by producing HB-EGF and amphiregulin (activators of the EGFR receptors family).

\subsubsection{Significance of the Effects of CCL18 on CAFs in the Neoplastic Tumor}

CAFs are the cells in the tumor niche responsible for the production and remodeling of the extracellular matrix [152-154]. They also secrete many factors, such as chemokines that support tumor growth. In breast phyllodes tumor, CCL18 participates in myofibroblast differentiation [39,155]. This process is dependent on the PITPNM3 receptor and the NF- $\mathrm{KB} \rightarrow \mathrm{miR}-21 \rightarrow$ tumor suppressor phosphatase and tensin homolog (PTEN) $\rightarrow$ Akt/PKB pathway, which is activated by this receptor [39]. As a result, the differentiating myofibroblasts begin remodeling the extracellular matrix, which has been proven on a collagen contraction assay. However, there are no detailed studies on the effects of CCL18 on CAFs in the neoplastic tumor.

CCL18 is a factor involved in the development of pulmonary fibrosis [156]. This chemokine increases the production of collagen in the fibroblasts [156-158]. This process may be CCR6-dependent [33]. The increase in the amount of collagen is also important in neoplastic processes $[152,153,159,160]$. Nevertheless, there are no studies available on the influence of CCL18 on the production of collagen in the neoplastic microenvironment.

\subsubsection{Role of Glycosaminoglycans in the Mechanisms of Action of CCL18}

Chemokines are a group of chemotactic cytokines that cause the activation of their receptors and the chemotaxis and migration of various types of cells. However, free chemokines have a poor ability to induce chemotaxis. Only after binding with glycosaminoglycans (GAGs) on the cell surface, do they show full activity $[21,161,162]$. Nevertheless, GAGs have a limited number of chemokine binding sites. For this reason, some chemokines that are less bound to GAGs are displaced by other chemokines that bind more strongly to them. An example of a chemokine that binds strongly to GAGs is CCL18 [37]. The high concentration of CCL18 in the neoplastic tumor causes the displacement of GAG-bound chemokines, which disrupts their functioning. CCL18 has been shown to interfere with 
16 of the 22 tested chemokines from the CC sub-family, as well as with 12 of the 15 chemokines tested from the CXC sub-family [37]. However, CCL18 displaces different chemokines to varying degrees. For instance, CCL2/MCP-1 and CCL5/RANTES are not significantly replaced by CCL18 [37]. These are important chemokines in the neoplastic processes, involved in the recruitment of TAMs into the tumor niche, angiogenesis and metastasis [114]. The chemokines more strongly displaced by CCL18 are CXCL14/breast and kidney chemokine (BRAK), CCL1/I-309, CCL11/Eotaxin-1, CCL19/MIP-3 $\beta$, CCL25/thymus expressed chemokine (TECK), and CCL26/Eotaxin-3. CXCL14/BRAK is an angiostatic and anti-tumor chemokine [163-165]. CCL11/Eotaxin-1, by recruiting eosinophils into the neoplastic niche, also has anti-tumor properties [166,167]. Therefore, CCL18 inhibits the action of some anti-cancer chemokines and, to a much lesser extent, pro-cancer ones.

CCL18 binding to GAGs has another important role in neoplastic processes. It allows extracellular vesicles to attach to target cells in the tumor microenvironment [168]. Extracellular vesicles are tiny membrane vesicles that are involved in extracellular communication [169]. They allow the transfer of miRNAs, mRNAs, and various proteins between cells. For this reason, they play an important role in neoplastic processes, in particular angiogenesis, migration, and metastasis, as well as in cancer immune evasion. They are secreted by different cells in the tumor niche, especially by tumor cells, and then they must be attached to the target cell. CCL18 plays a crucial role in this process [168]. This chemokine binds to GAGs on the extracellular vesicles. Next, GAG-bound CCL18 binds to its CCR8 receptor on the target cell. This allows extracellular vesicles to attach to the target cell, which is important in intercellular communication involving extracellular vesicles.

\section{CCL18 as a Tumor Marker}

CCL18 is a marker of neoplastic diseases. Studies on patients' material have shown that CCL18 expression is higher in tumor tissues than in normal ones in tumors such as cutaneous basal cell carcinoma [170], glioma [11,12], and breast cancer [171]. Additionally, the serum concentration of CCL18 is higher in cancer patients than in healthy individuals, especialy in cases of T-cell acute lymphoblastic leukemia [6], breast cancer [172,173], cutaneous T-cell lymphoma [148], laryngeal squamous cell carcinoma [174], non-small cell lung cancer [175,176], ovarian cancer [177], pancreatic ductal adenocarcinoma [59], and prostate cancer [178]. Moreover, in bladder cancer patients [179], the urinary concentration of CCL18 is higher than in healthy individuals. The level of CCL18 is proportional to the level of disease development: stage, Ki67 expression level in the tumor and lymph node metastasis $[12,171,172,175,180,181]$. Increased levels of CCL18 in the serum or the tumor are also associated with a worse prognosis for patients of cancers such as breast cancer $[39,69,108,173]$, cutaneous T-cell lymphoma [148], laryngeal squamous cell carcinoma [174], lung cancer [175,176], oral squamous cell carcinoma [182], ovarian cancer [55,177], osteosarcoma [56], pancreatic ductal adenocarcinoma [59,67], and esophageal squamous cell carcinoma [86]. An increased level of CCL18 in colorectal cancer [43] and gastric adenocarcinoma [44] is associated with a better prognosis. In non-small cell lung cancer, a greater infiltration of CCL18-producing cells is associated with a better prognosis [183], although the level of this chemokine in the plasma of patients with this type of cancer is associated with a worse prognosis [175] (Table 1). Nevertheless, the data in the Human Protein Atlas (https://www.proteinatlas.org) on the level of mRNA for CCL18 in tumors of various cancers do not confirm a clear relationship between an increased CCL18 expression and a worse survival [184,185] (Table 2). Taking into consideration 17 types of neoplasms, only in 4 cases an increased level of CCL18 is associated with a worse prognosis for patients, and in other 4, with a better one. However, there are no available data on the anti-cancer properties of CCL18. It is likely that this chemokine causes an increase in tumor-infiltrating lymphocytes (TILs) in the tumor [23], which, with an effective anti-tumor immune response, may improve the patient's prognosis [186]. 
Table 1. Prognosis for patients with increased CCL18 levels

\begin{tabular}{|c|c|c|c|c|}
\hline Type of Cancer & $\begin{array}{c}\text { Number of Patients } \\
\text { Studied }\end{array}$ & $\begin{array}{l}\text { Prognosis with } \\
\text { Increased CCL18 Levels } \\
\text { in the Tumor }\end{array}$ & Comments & Reference \\
\hline $\begin{array}{l}\text { Breast cancer (primary } \\
\text { ductal carcinoma) }\end{array}$ & 562 & $\downarrow$ & CCL18 $^{+}$TAM count & [69] \\
\hline Breast cancer & 1,017 & $\downarrow$ & $\begin{array}{c}\text { Serum level of CCL18 } \\
\text { and expression in } \\
\text { tumor }\end{array}$ & [108] \\
\hline Breast cancer & 207 & $\downarrow$ & Serum level of CCL18 & [173] \\
\hline Breast phyllodes tumor & 268 & $\downarrow$ & & [39] \\
\hline Colorectal cancer & 371 & $\uparrow$ & & [43] \\
\hline $\begin{array}{l}\text { Cutaneous T-cell } \\
\text { lymphoma }\end{array}$ & 38 & $\downarrow$ & Serum level of CCL18 & [148] \\
\hline Gastric adenocarcinoma & 90 & $\uparrow$ & & [44] \\
\hline $\begin{array}{l}\text { Laryngeal squamous cell } \\
\text { carcinoma }\end{array}$ & 146 & $\downarrow$ & Serum level of CCL18 & [174] \\
\hline $\begin{array}{c}\text { Lung cancer } \\
\text { (adenocarcinoma) }\end{array}$ & 170 & $\downarrow$ & Serum level of CCL18 & [176] \\
\hline $\begin{array}{l}\text { Lung cancer (non-small } \\
\text { cell lung cancer) }\end{array}$ & 80 & $\downarrow$ & Serum level of CCL18 & [175] \\
\hline $\begin{array}{l}\text { Lung cancer (non-small } \\
\text { cell lung cancer) }\end{array}$ & 243 & $\uparrow$ & CCL18 ${ }^{+}$TAM count & [183] \\
\hline $\begin{array}{l}\text { Oral squamous cell } \\
\text { carcinoma }\end{array}$ & 102 & $\downarrow$ & & [182] \\
\hline Ovarian cancer & 59 & $\downarrow$ & & [55] \\
\hline Ovarian cancer & 187 & $\downarrow$ & & [177] \\
\hline Osteosarcoma & 102 & $\downarrow$ & $\mathrm{CCL}^{2} 8^{+}$TAM count & [56] \\
\hline $\begin{array}{l}\text { Pancreatic ductal } \\
\text { adenocarcinoma }\end{array}$ & 62 & $\downarrow$ & CCL18 $^{+}$cells count & [59] \\
\hline $\begin{array}{l}\text { Pancreatic ductal } \\
\text { adenocarcinoma }\end{array}$ & 134 & $\downarrow$ & & [67] \\
\hline $\begin{array}{l}\text { Esophageal squamous } \\
\text { cell carcinoma }\end{array}$ & 25 & $\downarrow$ & & [86] \\
\hline
\end{tabular}


Table 2. Prognosis for a patient with a given tumor with an increased expression of the CCL18 chemokine and its receptors, according to The Human Protein Atlas (https://www.proteinatlas.org) [184,185].

\begin{tabular}{|c|c|c|c|c|c|c|}
\hline Type of Cancer & $\begin{array}{l}\text { Prognosis with an } \\
\text { Increased Expression } \\
\text { of CCL18 in the Tumor }\end{array}$ & $\begin{array}{l}\text { Prognosis with an } \\
\text { Increased Expression } \\
\text { of CCR6 in the Tumor }\end{array}$ & $\begin{array}{l}\text { Prognosis with an } \\
\text { Increased Expression } \\
\text { of CCR8 in the Tumor }\end{array}$ & $\begin{array}{c}\text { Prognosis with an Increased } \\
\text { Expression of PITPNM3 in } \\
\text { the Tumor }\end{array}$ & $\begin{array}{l}\text { Prognosis with an Increased } \\
\text { Expression of } \\
\text { GPER1/GPR30 in the Tumor }\end{array}$ & $\begin{array}{c}\text { Prognosis with an Increased } \\
\text { Expression of } \\
\text { GPER1/GPR30 in the Tumor } \\
\text { (In Men) }\end{array}$ \\
\hline Glioma & $\downarrow$ & $\uparrow p=0.076$ & $\downarrow$ & $\downarrow$ & - & - \\
\hline Thyroid cancer & - & - & - & - & $\downarrow p=0.073$ & $\downarrow$ \\
\hline Lung cancer & - & $\uparrow$ & $\uparrow$ & $\uparrow p=0.069$ & $\uparrow p=0.064$ & - \\
\hline Colorectal cancer & $\downarrow p=0.057$ & $\uparrow$ & - & $\uparrow$ & $\downarrow$ & $\downarrow p=0.064$ \\
\hline Head and neck cancer & $\uparrow$ & $\uparrow$ & $\uparrow$ & $\uparrow$ & $\uparrow p=0.062$ & $\uparrow p=0.093$ \\
\hline Stomach cancer & - & $\downarrow$ & $\uparrow p=0.080$ & $\uparrow p=0.096$ & $\downarrow$ & $\downarrow$ \\
\hline Liver cancer & - & - & - & $\uparrow$ & - & - \\
\hline Pancreatic cancer & $\downarrow$ & $\uparrow$ & $\uparrow p=0.074$ & $\downarrow$ & $\uparrow$ & $\uparrow p=0.057$ \\
\hline Renal cancer & $\uparrow$ & $\downarrow$ & $\downarrow$ & - & $\uparrow$ & $\uparrow$ \\
\hline Urothelial cancer & $\downarrow$ & - & - & - & $\downarrow p=0.078$ & $\downarrow p=0.091$ \\
\hline Prostate cancer & $\downarrow$ & $\uparrow$ & - & $\downarrow$ & - & - \\
\hline Testis cancer & - & $\downarrow p=0.080$ & $\downarrow$ & - & - & - \\
\hline Breast cancer & $\uparrow p=0.089$ & $\uparrow$ & - & $\downarrow$ & $\uparrow$ & N/A \\
\hline Cervical cancer & $\uparrow$ & $\uparrow$ & $\uparrow$ & $\uparrow$ & - & N/A \\
\hline Endometrial cancer & $\uparrow p=0.096$ & - & $\uparrow p=0.10$ & - & $\uparrow$ & N/A \\
\hline Ovarian cancer & $\uparrow$ & - & $\uparrow$ & $\downarrow$ & - & $\mathrm{N} / \mathrm{A}$ \\
\hline Melanoma & - & - & $\uparrow$ & $\downarrow$ & - & - \\
\hline
\end{tabular}




\section{CCL18 as a Therapeutic Target in Anti-Cancer Therapy}

CCL18 is produced in large amounts in every tumor $[6,12,170,175,178]$, where it participates in the recruitment of $\mathrm{T}_{\text {reg cells }}[50,116,129]$ and affects the phenotype of TAMs [110]. CCL18 is also involved in the migration, invasion and metastasis of many neoplastic tumors, although it is its role in the metastasis of breast cancer that has been best studied [27,63-65]. For this reason, understanding how CCL18 acts can be useful for anti-cancer therapy. Furthermore, the expression of CCL18 in TAMs may be determinant in the potential therapeutic approach. It has been shown that, in the presence of YKL-39+CCL18- TAM or YKL-39-CCL18 ${ }^{+}$TAM in a tumor, patients did not respond to neoadjuvant chemotherapy [187]. Nevertheless, more research is required to link CCL18 expression with the response to anti-cancer theraphy.

CCL18 is a potential therapeutic target for anti-cancer therapy. However, to date (second half of 2020), there is only one study focusing on the effects that blocking the activity of CCL18 would have on tumor development. Said study used SMC-21598 [65]. This is a compound that binds to CCL18, causing the chemokine to lose its biological properties. In vivo studies on NOD/SCID mice inoculated with MDA-MB-231 breast cancer cells showed that blocking CCL18 activity does not affect tumor growth or metastasis to the lungs [65]. This compound only blocks metastasis induced by CCL18 administration. Nevertheless, metastasis is a multi-factorial process, and more research is required in order to explore the correct therapeutic approach properly. Specifically, research is needed on the simultaneous application of multiple therapeutic approaches, such as blocking the activity of CCL18 and other pro-cancer factors. Hopefully, such studies will appear in the coming years.

Currently, no experimental work examining CCL18 as a therapeutic target in cancer other than breast cancer is available. However, studies on patients' prognosis have shown that an increased expression of CCL18 in tumors such as esophageal squamous cell carcinoma [86], glioma [185], oral squamous cell carcinoma [182], ovarian cancer [55,177], pancreatic cancer [67,185], prostate cancer [185], and urothelial cancer [185] is associated with a worse prognosis. This indicates that CCL18 plays an important pro-tumor role in these types of cancer. For this reason, future research on these diseases should mainly focus on developing therapeutic approaches that target CCL18.

Author Contributions: J.K.; writing-original draft preparation, M.O.; investigation, P.D.; investigation. All authors have read and agreed to the published version of the manuscript.

Funding: This study was supported by the statutory budget of the Department of Human Morphology and Embryology, Wroclaw Medical University, 50-368 Wroclaw, Poland.

Conflicts of Interest: The authors declare no conflict of interest.

$\begin{array}{ll}\text { Abbreviations } & \\ \text { CAF } & \text { Cancer-associated fibroblast } \\ \text { CCL } & \text { C-C motif chemokine ligand } \\ \text { CCR } & \text { C-C motif chemokine receptor } \\ \text { DC } & \text { Dendritic cell } \\ \text { EMT } & \text { Epithelial-to-mesenchymal transition } \\ \text { ERK } & \text { Extracellular signal-regulated kinase } \\ \text { IL } & \text { Interleukin } \\ \text { mTOR } & \text { Mammalian target of rapamycin } \\ \text { MAPK } & \text { Mitogen-activated protein kinase } \\ \text { NF-KB } & \text { Nuclear factor } \text { kB } \\ \text { PITPNM3 } & \text { Phosphatidylinositol transfer protein membrane-associated 3 } \\ \text { PI3K } & \text { Phosphatidylinositol-4,5-bisphosphate 3-kinase } \\ \text { PGE } 2 & \text { Prostaglandin E } \\ T_{\text {reg }} & \text { Regulatory T cell } \\ \text { TADC } & \text { Tumor-associated dendritic cell } \\ \text { TAM } & \text { Tumor-associated macrophage } \\ \text { TIL } & \text { Tumor-infiltrating lymphocyte }\end{array}$




\section{References}

1. Bray, F.; Ferlay, J.; Soerjomataram, I.; Siegel, R.L.; Torre, L.A.; Jemal, A. Global cancer statistics 2018: GLOBOCAN estimates of incidence and mortality worldwide for 36 cancers in 185 countries. CA Cancer J. Clin. 2018, 68, 394-424. [CrossRef] [PubMed]

2. GBD 2017 Causes of Death Collaborators. Global, regional, and national age-sex-specific mortality for 282 causes of death in 195 countries and territories, 1980-2017: A systematic analysis for the Global Burden of Disease Study 2017. Lancet 2018, 392, 1736-1788. [CrossRef]

3. André, F.E.; Foulkes, M.A. A phased approach to clinical testing: Criteria for progressing from Phase I to Phase II to Phase III studies. Dev. Biol. Stand. 1998, 95, 57-60. [PubMed]

4. Hanahan, D.; Weinberg, R.A. The hallmarks of cancer. Cell 2000, 100, 57-70. [CrossRef]

5. Hanahan, D.; Weinberg, R.A. Hallmarks of cancer: The next generation. Cell 2011, 144, 646-674. [CrossRef] [PubMed]

6. Struyf, S.; Schutyser, E.; Gouwy, M.; Gijsbers, K.; Proost, P.; Benoit, Y.; Opdenakker, G.; Van Damme, J.; Laureys, G. PARC/CCL18 is a plasma CC chemokine with increased levels in childhood acute lymphoblastic leukemia. Am. J. Pathol. 2003, 163, 2065-2075. [CrossRef]

7. Müller-Quernheim, U.C.; Potthast, L.; Müller-Quernheim, J.; Zissel, G. Tumor-cell co-culture induced alternative activation of macrophages is modulated by interferons in vitro. J. Interferon Cytokine Res. 2012, 32, 169-177. [CrossRef] [PubMed]

8. Zhang, A.; Qian, Y.; Ye, Z.; Chen, H.; Xie, H.; Zhou, L.; Shen, Y.; Zheng, S. Cancer-associated fibroblasts promote M2 polarization of macrophages in pancreatic ductal adenocarcinoma. Cancer Med. 2017, 6, 463-470. [CrossRef]

9. Sawa-Wejksza, K.; Dudek, A.; Lemieszek, M.; Kaławaj, K.; Kandefer-Szerszeń, M. Colon cancer-derived conditioned medium induces differentiation of THP-1 monocytes into a mixed population of M1/M2 cells. Tumour Biol. 2018, 40, 1010428318797880. [CrossRef]

10. Balkwill, F.R. The chemokine system and cancer. J. Pathol. 2012, 226, 148-157. [CrossRef]

11. Sharma, I.; Singh, A.; Sharma, K.C.; Saxena, S. Gene Expression Profiling of Chemokines and Their Receptors in Low and High Grade Astrocytoma. Asian Pac. J. Cancer Prev. 2017, 18, 1307-1313. [PubMed]

12. Ma, L.; Wang, H.; Li, Z.; Geng, X.; Li, M. Chemokine (C-C motif) ligand 18 is highly expressed in glioma tissues and promotes invasion of glioblastoma cells. J. Cancer Res. Ther. 2019, 15, 358-364.

13. Hieshima, K.; Imai, T.; Baba, M.; Shoudai, K.; Ishizuka, K.; Nakagawa, T.; Tsuruta, J.; Takeya, M.; Sakaki, Y.; Takatsuki, K.; et al. A novel human CC chemokine PARC that is most homologous to macrophage-inflammatory protein-1 alpha/LD78 alpha and chemotactic for T lymphocytes, but not for monocytes. J. Immunol. 1997, 159, 1140-1149.

14. Guan, P.; Burghes, A.H.; Cunningham, A.; Lira, P.; Brissette, W.H.; Neote, K.; McColl, S.R. Genomic organization and biological characterization of the novel human CC chemokine DC-CK-1/PARC/MIP-4/SCYA18. Genomics 1999, 56, 296-302. [CrossRef]

15. Kodelja, V.; Müller, C.; Politz, O.; Hakij, N.; Orfanos, C.E.; Goerdt, S. Alternative macrophage activation-associated CC-chemokine-1, a novel structural homologue of macrophage inflammatory protein-1 alpha with a Th2-associated expression pattern. J. Immunol. 1998, 160, 1411-1418. [PubMed]

16. Schutyser, E.; Struyf, S.; Proost, P.; Opdenakker, G.; Laureys, G.; Verhasselt, B.; Peperstraete, L.; Van de Putte, I.; Saccani, A.; Allavena, P.; et al. Identification of biologically active chemokine isoforms from ascitic fluid and elevated levels of CCL18/pulmonary and activation-regulated chemokine in ovarian carcinoma. J. Biol. Chem. 2002, 277, 24584-24593. [CrossRef]

17. Liang, W.G.; Ren, M.; Zhao, F.; Tang, W.J. Structures of human CCL18, CCL3, and CCL4 reveal molecular determinants for quaternary structures and sensitivity to insulin-degrading enzyme. J. Mol. Biol. 2015, 427, 1345-1358. [CrossRef] [PubMed]

18. Tasaki, Y.; Fukuda, S.; Iio, M.; Miura, R.; Imai, T.; Sugano, S.; Yoshie, O.; Hughes, A.L.; Nomiyama, H. Chemokine PARC gene (SCYA18) generated by fusion of two MIP-1alpha/LD78alpha-like genes. Genomics 1999, 55, 353-357. [CrossRef]

19. de Nadaï, P.; Charbonnier, A.S.; Chenivesse, C.; Sénéchal, S.; Fournier, C.; Gilet, J.; Vorng, H.; Chang, Y.; Gosset, P.; Wallaert, B.; et al. Involvement of CCL18 in allergic asthma. J. Immunol. 2006, 176, 6286-6293. [CrossRef] 
20. Lindhout, E.; Vissers, J.L.; Hartgers, F.C.; Huijbens, R.J.; Scharenborg, N.M.; Figdor, C.G.; Adema, G.J. The dendritic cell-specific CC-chemokine DC-CK1 is expressed by germinal center dendritic cells and attracts CD38-negative mantle zone B lymphocytes. J. Immunol. 2001, 166, 3284-3289. [CrossRef]

21. Krohn, S.; Garin, A.; Gabay, C.; Proudfoot, A.E. The Activity of CCL18 is Principally Mediated through Interaction with Glycosaminoglycans. Front. Immunol. 2013, 4, 193. [CrossRef] [PubMed]

22. Schraufstatter, I.; Takamori, H.; Sikora, L.; Sriramarao, P.; DiScipio, R.G. Eosinophils and monocytes produce pulmonary and activation-regulated chemokine, which activates cultured monocytes/macrophages. Am. J. Physiol. Lung Cell. Mol. Physiol. 2004, 286, L494-L501. [CrossRef]

23. Adema, G.J.; Hartgers, F.; Verstraten, R.; de Vries, E.; Marland, G.; Menon, S.; Foster, J.; Xu, Y.; Nooyen, P.; McClanahan, T.; et al. A dendritic-cell-derived C-C chemokine that preferentially attracts naive T cells. Nature 1997, 387, 713-717. [CrossRef]

24. Porcheray, F.; Viaud, S.; Rimaniol, A.C.; Léone, C.; Samah, B.; Dereuddre-Bosquet, N.; Dormont, D.; Gras, G. Macrophage activation switching: An asset for the resolution of inflammation. Clin. Exp. Immunol. 2005, 142, 481-489. [CrossRef]

25. Martinez, F.O.; Gordon, S.; Locati, M.; Mantovani, A. Transcriptional profiling of the human monocyte-to-macrophage differentiation and polarization: New molecules and patterns of gene expression. J. Immunol. 2006, 177, 7303-7311. [CrossRef]

26. Azzaoui, I.; Yahia, S.A.; Chang, Y.; Vorng, H.; Morales, O.; Fan, Y.; Delhem, N.; Ple, C.; Tonnel, A.B.; Wallaert, B.; et al. CCL18 differentiates dendritic cells in tolerogenic cells able to prime regulatory $\mathrm{T}$ cells in healthy subjects. Blood 2011, 118, 3549-3558. [CrossRef] [PubMed]

27. Hong, R.; Shen, M.H.; Xie, X.H.; Ruan, S.M. Inhibition of breast cancer metastasis via PITPNM3 by pachymic acid. Asian Pac. J. Cancer Prev. 2012, 13, 1877-1880. [CrossRef]

28. Chen, G.; Liang, Y.X.; Zhu, J.G.; Fu, X.; Chen, Y.F.; Mo, R.J.; Zhou, L.; Fu, H.; Bi, X.C.; He, H.C.; et al. CC chemokine ligand 18 correlates with malignant progression of prostate cancer. Biomed. Res. Int. 2014, 2014, 230183. [CrossRef] [PubMed]

29. Jiang, X.; Wang, J.; Chen, X.; Hong, Y.; Wu, T.; Chen, X.; Xia, J.; Cheng, B. Elevated autocrine chemokine ligand 18 expression promotes oral cancer cell growth and invasion via Akt activation. Oncotarget 2016, 7, 16262-16272. [CrossRef]

30. Shi, L.; Zhang, B.; Sun, X.; Zhang, X.; Lv, S.; Li, H.; Wang, X.; Zhao, C.; Zhang, H.; Xie, X.; et al. CC chemokine ligand 18(CCL18) promotes migration and invasion of lung cancer cells by binding to Nir1 through Nir1-ELMO1/DOC180 signaling pathway. Mol. Carcinog. 2016, 55, 2051-2062. [CrossRef]

31. Islam, S.A.; Ling, M.F.; Leung, J.; Shreffler, W.G.; Luster, A.D. Identification of human CCR8 as a CCL18 receptor. J. Exp. Med. 2013, 210, 1889-1898. [CrossRef]

32. Liu, X.; Xu, X.; Deng, W.; Huang, M.; Wu, Y.; Zhou, Z.; Zhu, K.; Wang, Y.; Cheng, X.; Zhou, X.; et al. CCL18 enhances migration, invasion and EMT by binding CCR8 in bladder cancer cells. Mol. Med. Rep. 2019, 19, 1678-1686. [CrossRef]

33. Zissel, G.; Höhne, K.; Kilic, A.; Maier, C.; Goldmann, T.; Prasse, A.; Ploenes, T.; Trepel, M.; Eibel, H.; Müller-Quernheim, J. Identification of the CCL18 Receptor-Effects of CCL18 on Human Lung Fibroblasts in Pulmonary Fibrosis are Mediated via CCR6. Pneumologie 2012, 66, P3_012. [CrossRef]

34. Catusse, J.; Wollner, S.; Leick, M.; Schröttner, P.; Schraufstätter, I.; Burger, M. Attenuation of CXCR4 responses by CCL18 in acute lymphocytic leukemia B cells. J. Cell. Physiol. 2010, 225, 792-800. [CrossRef]

35. Günther, C.; Zimmermann, N.; Berndt, N.; Grosser, M.; Stein, A.; Koch, A.; Meurer, M. Up-regulation of the chemokine CCL18 by macrophages is a potential immunomodulatory pathway in cutaneous T-cell lymphoma. Am. J. Pathol. 2011, 179, 1434-1442. [CrossRef]

36. Nibbs, R.J.; Salcedo, T.W.; Campbell, J.D.; Yao, X.T.; Li, Y.; Nardelli, B.; Olsen, H.S.; Morris, T.S.; Proudfoot, A.E.; Patel, V.P.; et al. C-C chemokine receptor 3 antagonism by the beta-chemokine macrophage inflammatory protein 4 , a property strongly enhanced by an amino-terminal alanine-methionine swap. J. Immunol. 2000, 164, 1488-1497. [CrossRef]

37. Krohn, S.C.; Bonvin, P.; Proudfoot, A.E. CCL18 exhibits a regulatory role through inhibition of receptor and glycosaminoglycan binding. PLoS ONE 2013, 8, e72321. [CrossRef] 
38. Zhou, Z.; Peng, Y.; Wu, X.; Meng, S.; Yu, W.; Zhao, J.; Zhang, H.; Wang, J.; Li, W. CCL18 secreted from M2 macrophages promotes migration and invasion via the PI3K/Akt pathway in gallbladder cancer. Cell. Oncol. 2019, 42, 81-92. [CrossRef] [PubMed]

39. Nie, Y.; Chen, J.; Huang, D.; Yao, Y.; Chen, J.; Ding, L.; Zeng, J.; Su, S.; Chao, X.; Su, F.; et al. Tumor-Associated Macrophages Promote Malignant Progression of Breast Phyllodes Tumors by Inducing Myofibroblast Differentiation. Cancer Res. 2017, 77, 3605-3618. [CrossRef] [PubMed]

40. Chang, C.Y.; Lee, Y.H.; Leu, S.J.; Wang, C.Y.; Wei, C.P.; Hung, K.S.; Pai, M.H.; Tsai, M.D.; Wu, C.H. CC-chemokine ligand 18/pulmonary activation-regulated chemokine expression in the CNS with special reference to traumatic brain injuries and neoplastic disorders. Neuroscience 2010, 165, 1233-1243. [CrossRef]

41. Pettersen, J.S.; Fuentes-Duculan, J.; Suárez-Fariñas, M.; Pierson, K.C.; Pitts-Kiefer, A.; Fan, L.; Belkin, D.A.; Wang, C.Q.; Bhuvanendran, S.; Johnson-Huang, L.M.; et al. Tumor-associated macrophages in the cutaneous SCC microenvironment are heterogeneously activated. J. Investig. Dermatol. 2011, 131, 1322-1330. [CrossRef]

42. Gabrusiewicz, K.; Rodriguez, B.; Wei, J.; Hashimoto, Y.; Healy, L.M.; Maiti, S.N.; Thomas, G.; Zhou, S.; Wang, Q.; Elakkad, A.; et al. Glioblastoma-infiltrated innate immune cells resemble M0 macrophage phenotype. JCI Insight 2016, 1, e85841. [CrossRef]

43. Yuan, R.; Chen, Y.; He, X.; Wu, X.; Ke, J.; Zou, Y.; Cai, Z.; Zeng, Y.; Wang, L.; Wang, J.; et al. CCL18 as an independent favorable prognostic biomarker in patients with colorectal cancer. J. Surg. Res. 2013, 183, 163-169. [CrossRef]

44. Leung, S.Y.; Yuen, S.T.; Chu, K.M.; Mathy, J.A.; Li, R.; Chan, A.S.; Law, S.; Wong, J.; Chen, X.; So, S. Expression profiling identifies chemokine (C-C motif) ligand 18 as an independent prognostic indicator in gastric cancer. Gastroenterology 2004, 127, 457-469. [CrossRef] [PubMed]

45. Peng, Q.; Zhao, L.; Hou, Y.; Sun, Y.; Wang, L.; Luo, H.; Peng, H.; Liu, M. Biological characteristics and genetic heterogeneity between carcinoma-associated fibroblasts and their paired normal fibroblasts in human breast cancer. PLoS ONE 2013, 8, e60321. [CrossRef]

46. Wu, J.; Long, Z.; Cai, H.; Du, C.; Liu, X.; Yu, S.; Wang, Y. High expression of WISP1 in colon cancer is associated with apoptosis, invasion and poor prognosis. Oncotarget 2016, 7, 49834-49847. [CrossRef]

47. Xu, L.; Zhang, Y.; Zhao, Z.; Chen, Z.; Wang, Z.; Xu, S.; Zhang, X.; Liu, T.; Yu, S. The long non-coding RNA CRNDE competed endogenously with miR-205 to promote proliferation and metastasis of melanoma cells by targeting CCL18. Cell Cycle 2018, 17, 2296-2308. [CrossRef]

48. Yang, C.M.; Ji, S.; Li, Y.; Fu, L.Y.; Jiang, T.; Meng, F.D. $\beta$-Catenin promotes cell proliferation, migration, and invasion but induces apoptosis in renal cell carcinoma. Onco Targets Ther. 2017, 10, 711-724. [CrossRef] [PubMed]

49. Chenivesse, C.; Chang, Y.; Azzaoui, I.; Ait Yahia, S.; Morales, O.; Plé, C.; Foussat, A.; Tonnel, A.B.; Delhem, N.; Yssel, H.; et al. Pulmonary CCL18 recruits human regulatory T cells. J. Immunol. 2012, 189, 128-137. [CrossRef]

50. Sun, Z.; Du, C.; Xu, P.; Miao, C. Surgical trauma-induced CCL18 promotes recruitment of regulatory T cells and colon cancer progression. J. Cell. Physiol. 2019, 234, 4608-4616. [CrossRef]

51. Ploenes, T.; Scholtes, B.; Krohn, A.; Burger, M.; Passlick, B.; Müller-Quernheim, J.; Zissel, G. CC-chemokine ligand 18 induces epithelial to mesenchymal transition in lung cancer A549 cells and elevates the invasive potential. PLoS ONE 2013, 8, e53068. [CrossRef] [PubMed]

52. Wang, L.; Wang, Y.X.; Chen, L.P.; Ji, M.L. Upregulation of microRNA-181b inhibits CCL18-induced breast cancer cell metastasis and invasion via the NF-кB signaling pathway. Oncol. Lett. 2016, 12, 4411-4418. [CrossRef] [PubMed]

53. Wang, L.; Wang, Y.X.; Zhang, D.Z.; Fang, X.J.; Sun, P.S.; Xue, H.C. Let-7a mimic attenuates CCL18 induced breast cancer cell metastasis through Lin 28 pathway. Biomed. Pharmacother. 2016, 78, 301-307. [CrossRef] [PubMed]

54. Zhou, Q.; Huang, L.; Gu, Y.; Lu, H.; Feng, Z. The expression of CCL18 in diffuse large B cell lymphoma and its mechanism research. Cancer Biomark. 2018, 21, 925-934. [CrossRef]

55. Wang, Q.; Tang, Y.; Yu, H.; Yin, Q.; Li, M.; Shi, L.; Zhang, W.; Li, D.; Li, L. CCL18 from tumor-cells promotes epithelial ovarian cancer metastasis via mTOR signaling pathway. Mol. Carcinog 2016, 55, 1688-1699. [CrossRef] 
56. Su, Y.; Zhou, Y.; Sun, Y.J.; Wang, Y.L.; Yin, J.Y.; Huang, Y.J.; Zhang, J.J.; He, A.N.; Han, K.; Zhang, H.Z.; et al. Macrophage-derived CCL18 promotes osteosarcoma proliferation and migration by upregulating the expression of UCA1. J. Mol. Med. 2019, 97, 49-61. [CrossRef]

57. Bo, S.; Donghao, S.; Guangqi, K.; Ye, T. CC Chemokine Ligand 18 Promotes Cell Proliferation and Metastasis of Urothelial Carcinoma via Activating PI3K/mTOR Signaling in Patient with Renal Transplantation. Urol. Int. 2018, 101, 450-458. [CrossRef] [PubMed]

58. Hou, X.; Zhang, Y.; Qiao, H. CCL18 promotes the invasion and migration of gastric cancer cells via ERK1/2/NF-кB signaling pathway. Tumour Biol. 2016, 37, 641-651. [CrossRef]

59. Meng, F.; Li, W.; Li, C.; Gao, Z.; Guo, K.; Song, S. CCL18 promotes epithelial-mesenchymal transition, invasion and migration of pancreatic cancer cells in pancreatic ductal adenocarcinoma. Int. J. Oncol. 2015, 46, 1109-1120. [CrossRef]

60. Wang, H.; Liang, X.; Li, M.; Tao, X.; Tai, S.; Fan, Z.; Wang, Z.; Cheng, B.; Xia, J. Chemokine (CC motif) ligand 18 upregulates Slug expression to promote stem-cell like features by activating the mammalian target of rapamycin pathway in oral squamous cell carcinoma. Cancer Sci. 2017, 108, 1584-1593. [CrossRef] [PubMed]

61. She, L.; Qin, Y.; Wang, J.; Liu, C.; Zhu, G.; Li, G.; Wei, M.; Chen, C.; Liu, G.; Zhang, D.; et al. Tumor-associated macrophages derived CCL18 promotes metastasis in squamous cell carcinoma of the head and neck. Cancer Cell Int. 2018, 18, 120. [CrossRef]

62. Lin, Z.; Li, W.; Zhang, H.; Wu, W.; Peng, Y.; Zeng, Y.; Wan, Y.; Wang, J.; Ouyang, N. CCL18/PITPNM3 enhances migration, invasion, and EMT through the NF- $\mathrm{kB}$ signaling pathway in hepatocellular carcinoma. Tumour Biol. 2016, 37, 3461-3468. [CrossRef]

63. Zhang, B.; Yin, C.; Li, H.; Shi, L.; Liu, N.; Sun, Y.; Lu, S.; Liu, Y.; Sun, L.; Li, X.; et al. Nir1 promotes invasion of breast cancer cells by binding to chemokine (C-C motif) ligand 18 through the PI3K/Akt/GSK3 $\beta /$ Snail signalling pathway. Eur. J. Cancer 2013, 49, 3900-3913. [CrossRef]

64. Li, H.; Zhang, D.; Yu, J.; Liu, H.; Chen, Z.; Zhong, H.; Wan, Y. CCL18-dependent translocation of AMAP1 is critical for epithelial to mesenchymal transition in breast cancer. J. Cell. Physiol. 2018, 233, 3207-3217. [CrossRef]

65. Liu, Y.; Zheng, H.; Li, Q.; Li, S.; Lai, H.; Song, E.; Li, D.; Chen, J. Discovery of CCL18 antagonist blocking breast cancer metastasis. Clin. Exp. Metastasis 2019, 36, 243-255. [CrossRef]

66. Lane, D.; Matte, I.; Laplante, C.; Garde-Granger, P.; Carignan, A.; Bessette, P.; Rancourt, C.; Piché, A. CCL18 from ascites promotes ovarian cancer cell migration through proline-rich tyrosine kinase 2 signaling. Mol. Cancer 2016, 15, 58. [CrossRef]

67. Ye, H.; Zhou, Q.; Zheng, S.; Li, G.; Lin, Q.; Wei, L.; Fu, Z.; Zhang, B.; Liu, Y.; Li, Z.; et al. Tumor-associated macrophages promote progression and the Warburg effect via CCL18/NF-kB/VCAM-1 pathway in pancreatic ductal adenocarcinoma. Cell Death Dis. 2018, 9, 453. [CrossRef]

68. Qin, Y.; Wang, J.; Zhu, G.; Li, G.; Tan, H.; Chen, C.; Pi, L.; She, L.; Chen, X.; Wei, M.; et al. CCL18 promotes the metastasis of squamous cell carcinoma of the head and neck through MTDH-NF- $\mathrm{kB}$ signalling pathway. J. Cell. Mol. Med. 2019, 23, 2689-2701. [CrossRef] [PubMed]

69. Chen, J.; Yao, Y.; Gong, C.; Yu, F.; Su, S.; Chen, J.; Liu, B.; Deng, H.; Wang, F.; Lin, L.; et al. CCL18 from tumor-associated macrophages promotes breast cancer metastasis via PITPNM3. Cancer Cell 2011, 19, 541-555. [CrossRef] [PubMed]

70. Jiang, X.; Huang, Z.; Sun, X.; Zheng, X.; Liu, J.; Shen, J.; Jia, B.; Luo, H.; Mai, Z.; Chen, G.; et al. CCL18-NIR1 promotes oral cancer cell growth and metastasis by activating the JAK2/STAT3 signaling pathway. BMC Cancer 2020, 20, 632. [CrossRef]

71. Shen, T.; Guo, Q. Role of Pyk2 in Human Cancers. Med. Sci. Monit. 2018, 24, 8172-8182. [CrossRef] [PubMed]

72. Min, C.; Eddy, S.F.; Sherr, D.H.; Sonenshein, G.E. NF-kappaB and epithelial to mesenchymal transition of cancer. J. Cell. Biochem. 2008, 104, 733-744. [CrossRef] [PubMed]

73. Tsubaki, M.; Komai, M.; Fujimoto, S.; Itoh, T.; Imano, M.; Sakamoto, K.; Shimaoka, H.; Takeda, T.; Ogawa, N.; Mashimo, K.; et al. Activation of NF-kB by the RANKL/RANK system up-regulates snail and twist expressions and induces epithelial-to-mesenchymal transition in mammary tumor cell lines. J. Exp. Clin. Cancer Res. 2013, 32, 62. [CrossRef] [PubMed] 
74. Pires, B.R.; Mencalha, A.L.; Ferreira, G.M.; de Souza, W.F.; Morgado-Díaz, J.A.; Maia, A.M.; Corrêa, S.; Abdelhay, E.S. NF-kappaB Is Involved in the Regulation of EMT Genes in Breast Cancer Cells. PLoS ONE 2017, 12, e0169622. [CrossRef] [PubMed]

75. Pham, T.H.; Bak, Y.; Kwon, T.; Kwon, S.B.; Oh, J.W.; Park, J.H.; Choi, Y.K.; Hong, J.T.; Yoon, D.Y. Interleukin-320 inhibits tumor-promoting effects of macrophage-secreted CCL18 in breast cancer. Cell Commun. Signal. 2019, 17, 53. [CrossRef] [PubMed]

76. Li, H.Y.; Cui, X.Y.; Wu, W.; Yu, F.Y.; Yao, H.R.; Liu, Q.; Song, E.W.; Chen, J.Q. Pyk2 and Src mediate signaling to CCL18-induced breast cancer metastasis. J. Cell. Biochem. 2014, 115, 596-603. [CrossRef]

77. Zhao, C.; Zheng, S.; Yan, Z.; Deng, Z.; Wang, R.; Zhang, B. CCL18 promotes the invasion and metastasis of breast cancer through Annexin A2. Oncol. Rep. 2020, 43, 571-580. [CrossRef] [PubMed]

78. Lin, X.; Chen, L.; Yao, Y.; Zhao, R.; Cui, X.; Chen, J.; Hou, K.; Zhang, M.; Su, F.; Chen, J.; et al. CCL18-mediated down-regulation of miR98 and miR27b promotes breast cancer metastasis. Oncotarget 2015, 6, 20485-20499. [CrossRef]

79. Wang, Y.; Shi, J.; Chai, K.; Ying, X.; Zhou, B.P. The Role of Snail in EMT and Tumorigenesis. Curr. Cancer Drug Targets 2013, 13, 963-972. [CrossRef]

80. Song, X.; Liu, W.; Yuan, X.; Jiang, J.; Wang, W.; Mullen, M.; Zhao, X.; Zhang, Y.; Liu, F.; Du, S.; et al. Acetylation of ACAP4 regulates CCL18-elicited breast cancer cell migration and invasion. J. Mol. Cell Biol. 2018, 10, 559-572. [CrossRef]

81. Song, X.; Wang, W.; Wang, H.; Yuan, X.; Yang, F.; Zhao, L.; Mullen, M.; Du, S.; Zohbi, N.; Muthusamy, S.; et al. Acetylation of ezrin regulates membrane-cytoskeletal interaction underlying CCL18-elicited cell migration. J. Mol. Cell Biol. 2020, 12, 424-437. [CrossRef] [PubMed]

82. Murugan, A.K. mTOR: Role in cancer, metastasis and drug resistance. Semin. Cancer Biol. 2019, 59, 92-111. [CrossRef]

83. Jing, X.; Peng, J.; Dou, Y.; Sun, J.; Ma, C.; Wang, Q.; Zhang, L.; Luo, X.; Kong, B.; Zhang, Y.; et al. Macrophage $\mathrm{ER} \alpha$ promoted invasion of endometrial cancer cell by mTOR/KIF5B-mediated epithelial to mesenchymal transition. Immunol. Cell Biol. 2019, 97, 563-576. [CrossRef] [PubMed]

84. Song, H.; Tao, Y.; Ni, N.; Zhou, X.; Xiong, J.; Zeng, X.; Xu, X.; Qi, J.; Sun, J. miR-128 targets the CC chemokine ligand 18 gene (CCL18) in cutaneous malignant melanoma progression. J. Dermatol. Sci. 2018, 91, 317-324. [CrossRef]

85. $\mathrm{Li}, \mathrm{T}$; Sun, $\mathrm{X} . ; \mathrm{Xu}, \mathrm{K}$. The suppressing role of miR-622 in renal cell carcinoma progression by down-regulation of CCL18/MAPK signal pathway. Cell Biosci. 2018, 8, 17. [CrossRef] [PubMed]

86. Wang, W.; Wu, D.; He, X.; Hu, X.; Hu, C.; Shen, Z.; Lin, J.; Pan, Z.; He, Z.; Lin, H.; et al. CCL18-induced HOTAIR upregulation promotes malignant progression in esophageal squamous cell carcinoma through the miR-130a-5p-ZEB1 axis. Cancer Lett. 2019, 460, 18-28. [CrossRef] [PubMed]

87. Span, P.N.; Bussink, J. Biology of hypoxia. Semin. Nucl. Med. 2015, 45, 101-109. [CrossRef]

88. Bielenberg, D.R.; Zetter, B.R. The Contribution of Angiogenesis to the Process of Metastasis. Cancer J. 2015, 21, 267-273. [CrossRef]

89. De Palma, M.; Biziato, D.; Petrova, T.V. Microenvironmental regulation of tumour angiogenesis. Nat. Rev. Cancer 2017, 17, 457-474. [CrossRef]

90. Lin, L.; Chen, Y.S.; Yao, Y.D.; Chen, J.Q.; Chen, J.N.; Huang, S.Y.; Zeng, Y.J.; Yao, H.R.; Zeng, S.H.; $\mathrm{Fu}, \mathrm{Y} . \mathrm{S}$; et al. CCL18 from tumor-associated macrophages promotes angiogenesis in breast cancer. Oncotarget 2015, 6, 34758-34773. [CrossRef]

91. Bosco, M.C.; Puppo, M.; Santangelo, C.; Anfosso, L.; Pfeffer, U.; Fardin, P.; Battaglia, F.; Varesio, L. Hypoxia modifies the transcriptome of primary human monocytes: Modulation of novel immune-related genes and identification of CC-chemokine ligand 20 as a new hypoxia-inducible gene. J. Immunol. 2006, 177, 1941-1955. [CrossRef]

92. Ricciardi, A.; Elia, A.R.; Cappello, P.; Puppo, M.; Vanni, C.; Fardin, P.; Eva, A.; Munroe, D.; Wu, X.; Giovarelli, M.; et al. Transcriptome of hypoxic immature dendritic cells: Modulation of chemokine/receptor expression. Mol. Cancer Res. 2008, 6, 175-185. [CrossRef]

93. Blengio, F.; Raggi, F.; Pierobon, D.; Cappello, P.; Eva, A.; Giovarelli, M.; Varesio, L.; Bosco, M.C. The hypoxic environment reprograms the cytokine/chemokine expression profile of human mature dendritic cells. Immunobiology 2013, 218, 76-89. [CrossRef] 
94. Dehne, N.; Brüne, B. Hypoxic inhibition of JMJD3 reduces H3K27me3 demethylation and induction of the STAT6 target gene CCL18. Biochim. Biophys. Acta 2016, 1859, 1490-1501. [CrossRef]

95. Chanmee, T.; Ontong, P.; Konno, K.; Itano, N. Tumor-associated macrophages as major players in the tumor microenvironment. Cancers 2014, 6, 1670-1690. [CrossRef]

96. Xu, L.; Zhu, Y.; Chen, L.; An, H.; Zhang, W.; Wang, G.; Lin, Z.; Xu, J. Prognostic value of diametrically polarized tumor-associated macrophages in renal cell carcinoma. Ann. Surg. Oncol. 2014, 21, 3142-3150. [CrossRef]

97. Zhang, H.; Wang, X.; Shen, Z.; Xu, J.; Qin, J.; Sun, Y. Infiltration of diametrically polarized macrophages predicts overall survival of patients with gastric cancer after surgical resection. Gastric Cancer 2015, 18, 740-750. [CrossRef]

98. Yuan, X.; Zhang, J.; Li, D.; Mao, Y.; Mo, F.; Du, W.; Ma, X. Prognostic significance of tumor-associated macrophages in ovarian cancer: A meta-analysis. Gynecol. Oncol. 2017, 147, 181-187. [CrossRef]

99. Qian, B.Z.; Li, J.; Zhang, H.; Kitamura, T.; Zhang, J.; Campion, L.R.; Kaiser, E.A.; Snyder, L.A.; Pollard, J.W. CCL2 recruits inflammatory monocytes to facilitate breast-tumour metastasis. Nature 2011, 475, $222-225$. [CrossRef]

100. Walens, A.; DiMarco, A.V.; Lupo, R.; Kroger, B.R.; Damrauer, J.S.; Alvarez, J.V. CCL5 promotes breast cancer recurrence through macrophage recruitment in residual tumors. Elife 2019, 8, e43653. [CrossRef]

101. Chen, X.J.; Deng, Y.R.; Wang, Z.C.; Wei, W.F.; Zhou, C.F.; Zhang, Y.M.; Yan, R.M.; Liang, L.J.; Zhong, M.; Liang, L.; et al. Hypoxia-induced ZEB1 promotes cervical cancer progression via CCL8-dependent tumour-associated macrophage recruitment. Cell Death Dis. 2019, 10, 508. [CrossRef] [PubMed]

102. Gupta, S.; Jain, A.; Syed, S.N.; Snodgrass, R.G.; Pflüger-Müller, B.; Leisegang, M.S.; Weigert, A.; Brandes, R.P.; Ebersberger, I.; Brüne, B.; et al. IL-6 augments IL-4-induced polarization of primary human macrophages through synergy of STAT3, STAT6 and BATF transcription factors. Oncoimmunology 2018, 7, e1494110. [CrossRef] [PubMed]

103. Mazzoni, M.; Mauro, G.; Erreni, M.; Romeo, P.; Minna, E.; Vizioli, M.G.; Belgiovine, C.; Rizzetti, M.G.; Pagliardini, S.; Avigni, R.; et al. Senescent thyrocytes and thyroid tumor cells induce M2-like macrophage polarization of human monocytes via a PGE2-dependent mechanism. J. Exp. Clin. Cancer Res. 2019, 38, 208. [CrossRef] [PubMed]

104. Tiemessen, M.M.; Jagger, A.L.; Evans, H.G.; van Herwijnen, M.J.; John, S.; Taams, L.S. CD4+CD25+Foxp3+ regulatory T cells induce alternative activation of human monocytes/macrophages. Proc. Natl. Acad. Sci. USA 2007, 104, 19446-19451. [CrossRef] [PubMed]

105. El-Kenawi, A.; Gatenbee, C.; Robertson-Tessi, M.; Bravo, R.; Dhillon, J.; Balagurunathan, Y.; Berglund, A.; Vishvakarma, N.; Ibrahim-Hashim, A.; Choi, J.; et al. Acidity promotes tumour progression by altering macrophage phenotype in prostate cancer. Br. J. Cancer 2019, 121, 556-566. [CrossRef] [PubMed]

106. Mu, X.; Shi, W.; Xu, Y.; Xu, C.; Zhao, T.; Geng, B.; Yang, J.; Pan, J.; Hu, S.; Zhang, C.; et al. Tumor-derived lactate induces M2 macrophage polarization via the activation of the ERK/STAT3 signaling pathway in breast cancer. Cell Cycle 2018, 17, 428-438. [CrossRef] [PubMed]

107. Pinto, M.L.; Rios, E.; Silva, A.C.; Neves, S.C.; Caires, H.R.; Pinto, A.T.; Durães, C.; Carvalho, F.A.; Cardoso, A.P.; Santos, N.C.; et al. Decellularized human colorectal cancer matrices polarize macrophages towards an anti-inflammatory phenotype promoting cancer cell invasion via CCL18. Biomaterials 2017, 124, 211-224. [CrossRef]

108. Su, S.; Liu, Q.; Chen, J.; Chen, J.; Chen, F.; He, C.; Huang, D.; Wu, W.; Lin, L.; Huang, W.; et al. A positive feedback loop between mesenchymal-like cancer cells and macrophages is essential to breast cancer metastasis. Cancer Cell 2014, 25, 605-620. [CrossRef]

109. Wang, T.T.; Yuan, J.H.; Ma, J.Z.; Yang, W.J.; Liu, X.N.; Yin, Y.P.; Liu, Y.; Pan, W.; Sun, S.H. CTGF secreted by mesenchymal-like hepatocellular carcinoma cells plays a role in the polarization of macrophages in hepatocellular carcinoma progression. Biomed. Pharmacother. 2017, 95, 111-119. [CrossRef]

110. Schraufstatter, I.U.; Zhao, M.; Khaldoyanidi, S.K.; Discipio, R.G. The chemokine CCL18 causes maturation of cultured monocytes to macrophages in the M2 spectrum. Immunology 2012, 135, 287-298. [CrossRef]

111. Wimmer, A.; Khaldoyanidi, S.K.; Judex, M.; Serobyan, N.; Discipio, R.G.; Schraufstatter, I.U. CCL18/PARC stimulates hematopoiesis in long-term bone marrow cultures indirectly through its effect on monocytes. Blood 2006, 108, 3722-3729. [CrossRef] 
112. Yuan, M.; Zhu, H.; Xu, J.; Zheng, Y.; Cao, X.; Liu, Q. Tumor-Derived CXCL1 Promotes Lung Cancer Growth via Recruitment of Tumor-Associated Neutrophils. J. Immunol. Res. 2016, 2016, 6530410. [CrossRef]

113. Shi, H.; Han, X.; Sun, Y.; Shang, C.; Wei, M.; Ba, X.; Zeng, X. Chemokine (C-X-C motif) ligand 1 and CXCL2 produced by tumor promote the generation of monocytic myeloid-derived suppressor cells. Cancer Sci. 2018, 109, 3826-3839. [CrossRef] [PubMed]

114. Soria, G.; Ben-Baruch, A. The inflammatory chemokines CCL2 and CCL5 in breast cancer. Cancer Lett. 2008, 267, 271-285. [CrossRef]

115. Miyake, M.; Goodison, S.; Urquidi, V.; Gomes Giacoia, E.; Rosser, C.J. Expression of CXCL1 in human endothelial cells induces angiogenesis through the CXCR2 receptor and the ERK1/2 and EGF pathways. Lab. Investig. 2013, 93, 768-778. [CrossRef]

116. Duluc, D.; Corvaisier, M.; Blanchard, S.; Catala, L.; Descamps, P.; Gamelin, E.; Ponsoda, S.; Delneste, Y.; Hebbar, M.; Jeannin, P. Interferon-gamma reverses the immunosuppressive and protumoral properties and prevents the generation of human tumor-associated macrophages. Int. J. Cancer 2009, 125, 367-373. [CrossRef]

117. Furudate, S.; Fujimura, T.; Kakizaki, A.; Hidaka, T.; Asano, M.; Aiba, S. Tumor-associated M2 macrophages in mycosis fungoides acquire immunomodulatory function by interferon alpha and interferon gamma. J. Dermatol. Sci. 2016, 83, 182-189. [CrossRef] [PubMed]

118. Attias, M.; Al-Aubodah, T.; Piccirillo, C.A. Mechanisms of human FoxP3+ Treg cell development and function in health and disease. Clin. Exp. Immunol. 2019, 197, 36-51.

119. Iellem, A.; Mariani, M.; Lang, R.; Recalde, H.; Panina-Bordignon, P.; Sinigaglia, F.; D'Ambrosio, D. Unique chemotactic response profile and specific expression of chemokine receptors CCR4 and CCR8 by CD4(+)CD25(+) regulatory T cells. J. Exp. Med. 2001, 194, 847-853. [CrossRef]

120. Plitas, G.; Konopacki, C.; Wu, K.; Bos, P.D.; Morrow, M.; Putintseva, E.V.; Chudakov, D.M.; Rudensky, A.Y. Regulatory T Cells Exhibit Distinct Features in Human Breast Cancer. Immunity 2016, 45, 1122-1134. [CrossRef]

121. Xu, Y.; Dong, X.; Qi, P.; Ye, Y.; Shen, W.; Leng, L.; Wang, L.; Li, X.; Luo, X.; Chen, Y.; et al. Sox2 Communicates with Tregs Through CCL1 to Promote the Stemness Property of Breast Cancer Cells. Stem Cells 2017, 35, 2351-2365. [CrossRef] [PubMed]

122. Kuehnemuth, B.; Piseddu, I.; Wiedemann, G.M.; Lauseker, M.; Kuhn, C.; Hofmann, S.; Schmoeckel, E.; Endres, S.; Mayr, D.; Jeschke, U.; et al. CCL1 is a major regulatory T cell attracting factor in human breast cancer. BMC Cancer 2018, 18, 1278. [CrossRef] [PubMed]

123. Mizukami, Y.; Kono, K.; Kawaguchi, Y.; Akaike, H.; Kamimura, K.; Sugai, H.; Fujii, H. CCL17 and CCL22 chemokines within tumor microenvironment are related to accumulation of Foxp3+ regulatory $\mathrm{T}$ cells in gastric cancer. Int. J. Cancer 2008, 122, 2286-2293. [CrossRef] [PubMed]

124. Wiedemann, G.M.; Röhrle, N.; Makeschin, M.C.; Fesseler, J.; Endres, S.; Mayr, D.; Anz, D. Peritumoural CCL1 and CCL22 expressing cells in hepatocellular carcinomas shape the tumour immune infiltrate. Pathology 2019, 51, 586-592. [CrossRef]

125. Ren, L.; Yu, Y.; Wang, L.; Zhu, Z.; Lu, R.; Yao, Z. Hypoxia-induced CCL28 promotes recruitment of regulatory $\mathrm{T}$ cells and tumor growth in liver cancer. Oncotarget 2016, 7, 75763-75773. [CrossRef]

126. Liu, J.; Zhang, N.; Li, Q.; Zhang, W.; Ke, F.; Leng, Q.; Wang, H.; Chen, J.; Wang, H. Tumor-associated macrophages recruit CCR6+ regulatory $\mathrm{T}$ cells and promote the development of colorectal cancer via enhancing CCL20 production in mice. PLoS ONE 2011, 6, e19495. [CrossRef]

127. Chen, K.J.; Lin, S.Z.; Zhou, L.; Xie, H.Y.; Zhou, W.H.; Taki-Eldin, A.; Zheng, S.S. Selective recruitment of regulatory T cell through CCR6-CCL20 in hepatocellular carcinoma fosters tumor progression and predicts poor prognosis. PLoS ONE 2011, 6, e24671. [CrossRef]

128. Zhang, C.Y.; Qi, Y.; Li, X.N.; Yang, Y.; Liu, D.L.; Zhao, J.; Zhu, D.Y.; Wu, K.; Zhou, X.D.; Zhao, S. The role of CCL20/CCR6 axis in recruiting Treg cells to tumor sites of NSCLC patients. Biomed. Pharmacother. 2015, 69, 242-248. [CrossRef]

129. Su, S.; Liao, J.; Liu, J.; Huang, D.; He, C.; Chen, F.; Yang, L.; Wu, W.; Chen, J.; Lin, L.; et al. Blocking the recruitment of naive CD4+ T cells reverses immunosuppression in breast cancer. Cell Res. 2017, 27, 461-482. [CrossRef] 
130. Hoves, S.; Krause, S.W.; Schütz, C.; Halbritter, D.; Schölmerich, J.; Herfarth, H.; Fleck, M. Monocyte-derived human macrophages mediate anergy in allogeneic $\mathrm{T}$ cells and induce regulatory T cells. J. Immunol. 2006, 177, 2691-2698. [CrossRef]

131. Wang, C.; Lee, J.H.; Kim, C.H. Optimal population of FoxP3+ T cells in tumors requires an antigen priming-dependent trafficking receptor switch. PLoS ONE 2012, 7, e30793. [CrossRef] [PubMed]

132. Chang, Y.; de Nadai, P.; Azzaoui, I.; Morales, O.; Delhem, N.; Vorng, H.; Tomavo, S.; Ait Yahia, S.; Zhang, G.; Wallaert, B.; et al. The chemokine CCL18 generates adaptive regulatory T cells from memory CD4+ T cells of healthy but not allergic subjects. FASEB J. 2010, 24, 5063-5072. [PubMed]

133. Wang, L.; Simons, D.L.; Lu, X.; Tu, T.Y.; Solomon, S.; Wang, R.; Rosario, A.; Avalos, C.; Schmolze, D.; Yim, J.; et al. Connecting blood and intratumoral Treg cell activity in predicting future relapse in breast cancer. Nat. Immunol. 2019, 20, 1220-1230. [CrossRef] [PubMed]

134. Mohr, A.; Malhotra, R.; Mayer, G.; Gorochov, G.; Miyara, M. Human FOXP3+ T regulatory cell heterogeneity. Clin. Transl. Immunol. 2018, 7, e1005. [CrossRef] [PubMed]

135. Middel, P.; Brauneck, S.; Meyer, W.; Radzun, H.J. Chemokine-mediated distribution of dendritic cell subsets in renal cell carcinoma. BMC Cancer 2010, 10, 578. [CrossRef] [PubMed]

136. Fernandez, N.C.; Flament, C.; Crépineau, F.; Angevin, E.; Vivier, E.; Zitvogel, L. Dendritic cells (DC) promote natural killer (NK) cell functions: Dynamics of the human DC/NK cell cross talk. Eur. Cytokine Netw. 2002, 13, 17-27.

137. Sarhan, D.; Palma, M.; Mao, Y.; Adamson, L.; Kiessling, R.; Mellstedt, H.; Österborg, A.; Lundqvist, A. Dendritic cell regulation of NK-cell responses involves lymphotoxin- $\alpha$, IL-12, and TGF- $\beta$. Eur. J. Immunol. 2015, 45, 1783-1793. [CrossRef]

138. Leone, P.; Berardi, S.; Frassanito, M.A.; Ria, R.; De Re, V.; Cicco, S.; Battaglia, S.; Ditonno, P.; Dammacco, F.; Vacca, A.; et al. Dendritic cells accumulate in the bone marrow of myeloma patients where they protect tumor plasma cells from CD8+ T-cell killing. Blood 2015, 126, 1443-1451. [CrossRef]

139. Chan, C.W.; Housseau, F. The 'kiss of death' by dendritic cells to cancer cells. Cell Death Differ. 2008, 15, 58-69. [CrossRef]

140. Charles, J.; Di Domizio, J.; Salameire, D.; Bendriss-Vermare, N.; Aspord, C.; Muhammad, R.; Lefebvre, C.; Plumas, J.; Leccia, M.T.; Chaperot, L. Characterization of circulating dendritic cells in melanoma: Role of CCR6 in plasmacytoid dendritic cell recruitment to the tumor. J. Investig. Dermatol. 2010, 130, 1646-1656. [CrossRef]

141. Vulcano, M.; Struyf, S.; Scapini, P.; Cassatella, M.; Bernasconi, S.; Bonecchi, R.; Calleri, A.; Penna, G.; Adorini, L.; Luini, W.; et al. Unique regulation of CCL18 production by maturing dendritic cells. J. Immunol. 2003, 170, 3843-3849. [CrossRef]

142. Yu, G.; Fang, M.; Gong, M.; Liu, L.; Zhong, J.; Feng, W.; Xiong, P.; Wang, C.Y.; Gong, F. Steady state dendritic cells with forced IDO expression induce skin allograft tolerance by upregulation of regulatory $\mathrm{T}$ cells. Transpl. Immunol. 2008, 18, 208-219. [CrossRef]

143. Hsu, Y.L.; Huang, M.S.; Cheng, D.E.; Hung, J.Y.; Yang, C.J.; Chou, S.H.; Kuo, P.L. Lung tumor-associated dendritic cell-derived amphiregulin increased cancer progression. J. Immunol. 2011, 187, 1733-1744. [CrossRef]

144. Kuo, P.L.; Huang, M.S.; Cheng, D.E.; Hung, J.Y.; Yang, C.J.; Chou, S.H. Lung cancer-derived galectin-1 enhances tumorigenic potentiation of tumor-associated dendritic cells by expressing heparin-binding EGF-like growth factor. J. Biol. Chem. 2012, 287, 9753-9764. [CrossRef]

145. Kan, J.Y.; Wu, D.C.; Yu, F.J.; Wu, C.Y.; Ho, Y.W.; Chiu, Y.J.; Jian, S.F.; Hung, J.Y.; Wang, J.Y.; Kuo, P.L. Chemokine (C-C Motif) Ligand 5 is Involved in Tumor-Associated Dendritic Cell-Mediated Colon Cancer Progression Through Non-Coding RNA MALAT-1. J. Cell. Physiol. 2015, 230, 1883-1894. [CrossRef]

146. von Bergwelt-Baildon, M.S.; Popov, A.; Saric, T.; Chemnitz, J.; Classen, S.; Stoffel, M.S.; Fiore, F.; Roth, U.; Beyer, M.; Debey, S.; et al. CD25 and indoleamine 2,3-dioxygenase are up-regulated by prostaglandin E2 and expressed by tumor-associated dendritic cells in vivo: Additional mechanisms of T-cell inhibition. Blood 2006, 108, 228-237. [CrossRef]

147. Cheng, D.E.; Tsai, Y.M.; Hsu, Y.L.; Hou, M.F.; Tsai, E.M.; Wang, J.Y.; Kan, J.Y.; Kuo, P.L. Cluster of differentiation 45 activation is crucial in interleukin-10-dependent tumor-associated dendritic cell differentiation. Oncol. Lett. 2014, 8, 620-626. [CrossRef] [PubMed] 
148. Miyagaki, T.; Sugaya, M.; Suga, H.; Ohmatsu, H.; Fujita, H.; Asano, Y.; Tada, Y.; Kadono, T.; Sato, S. Increased CCL18 expression in patients with cutaneous T-cell lymphoma: Association with disease severity and prognosis. J. Eur. Acad. Dermatol. Venereol. 2013, 27, e60-e67. [CrossRef] [PubMed]

149. Jonuleit, H.; Schmitt, E.; Schuler, G.; Knop, J.; Enk, A.H. Induction of interleukin 10-producing, nonproliferating $\mathrm{CD} 4(+) \mathrm{T}$ cells with regulatory properties by repetitive stimulation with allogeneic immature human dendritic cells. J. Exp. Med. 2000, 192, 1213-1222. [CrossRef]

150. Wainwright, D.A.; Balyasnikova, I.V.; Chang, A.L.; Ahmed, A.U.; Moon, K.S.; Auffinger, B.; Tobias, A.L.; Han, Y.; Lesniak, M.S. IDO expression in brain tumors increases the recruitment of regulatory T cells and negatively impacts survival. Clin. Cancer Res. 2012, 18, 6110-6121. [CrossRef]

151. Munn, D.H.; Mellor, A.L. IDO in the Tumor Microenvironment: Inflammation, Counter-Regulation, and Tolerance. Trends Immunol. 2016, 37, 193-207. [CrossRef] [PubMed]

152. van Kempen, L.C.; Rijntjes, J.; Mamor-Cornelissen, I.; Vincent-Naulleau, S.; Gerritsen, M.J.; Ruiter, D.J.; van Dijk, M.C.; Geffrotin, C.; van Muijen, G.N. Type I collagen expression contributes to angiogenesis and the development of deeply invasive cutaneous melanoma. Int. J. Cancer 2008, 122, 1019-1029. [CrossRef]

153. Wang, K.; Wu, F.; Seo, B.R.; Fischbach, C.; Chen, W.; Hsu, L.; Gourdon, D. Breast cancer cells alter the dynamics of stromal fibronectin-collagen interactions. Matrix Biol. 2017, 60-61, 86-95. [CrossRef] [PubMed]

154. Kalluri, R. The biology and function of fibroblasts in cancer. Nat. Rev. Cancer 2016, 16, 582-598. [CrossRef]

155. Nie, Y.; Huang, H.; Guo, M.; Chen, J.; Wu, W.; Li, W.; Xu, X.; Lin, X.; Fu, W.; Yao, Y.; et al. Breast Phyllodes Tumors Recruit and Repolarize Tumor-Associated Macrophages via Secreting CCL5 to Promote Malignant Progression, Which Can Be Inhibited by CCR5 Inhibition Therapy. Clin. Cancer Res. 2019, 25, 3873-3886. [CrossRef] [PubMed]

156. Atamas, S.P.; Luzina, I.G.; Choi, J.; Tsymbalyuk, N.; Carbonetti, N.H.; Singh, I.S.; Trojanowska, M.; Jimenez, S.A.; White, B. Pulmonary and activation-regulated chemokine stimulates collagen production in lung fibroblasts. Am. J. Respir. Cell Mol. Biol. 2003, 29, 743-749. [CrossRef] [PubMed]

157. Luzina, I.G.; Highsmith, K.; Pochetuhen, K.; Nacu, N.; Rao, J.N.; Atamas, S.P. PKCalpha mediates CCL18-stimulated collagen production in pulmonary fibroblasts. Am. J. Respir. Cell Mol. Biol. 2006, 35, 298-305. [CrossRef]

158. Prasse, A.; Pechkovsky, D.V.; Toews, G.B.; Jungraithmayr, W.; Kollert, F.; Goldmann, T.; Vollmer, E.; Müller-Quernheim, J.; Zissel, G. A vicious circle of alveolar macrophages and fibroblasts perpetuates pulmonary fibrosis via CCL18. Am. J. Respir. Crit. Care Med. 2006, 173, 781-792. [CrossRef]

159. Hanley, C.J.; Noble, F.; Ward, M.; Bullock, M.; Drifka, C.; Mellone, M.; Manousopoulou, A.; Johnston, H.E.; Hayden, A.; Thirdborough, S.; et al. A subset of myofibroblastic cancer-associated fibroblasts regulate collagen fiber elongation, which is prognostic in multiple cancers. Oncotarget 2016, 7, 6159-6174. [CrossRef]

160. Begum, A.; McMillan, R.H.; Chang, Y.T.; Penchev, V.R.; Rajeshkumar, N.V.; Maitra, A.; Goggins, M.G.; Eshelman, J.R.; Wolfgang, C.L.; Rasheed, Z.A.; et al. Direct Interactions with Cancer-Associated Fibroblasts Lead to Enhanced Pancreatic Cancer Stem Cell Function. Pancreas 2019, 48, 329-334. [CrossRef]

161. Verkaar, F.; van Offenbeek, J.; van der Lee, M.M.C.; van Lith, L.H.C.J.; Watts, A.O.; Rops, A.L.W.M.M.; Aguilar, D.C.; Ziarek, J.J.; van der Vlag, J.; Handel, T.M.; et al. Chemokine cooperativity is caused by competitive glycosaminoglycan binding. J. Immunol. 2014, 192, 3908-3914. [CrossRef] [PubMed]

162. Proudfoot, A.E.I.; Johnson, Z.; Bonvin, P.; Handel, T.M. Glycosaminoglycan Interactions with Chemokines Add Complexity to a Complex System. Pharmaceuticals 2017, 10, 70. [CrossRef] [PubMed]

163. Shellenberger, T.D.; Wang, M.; Gujrati, M.; Jayakumar, A.; Strieter, R.M.; Burdick, M.D.; Ioannides, C.G.; Efferson, C.L.; El-Naggar, A.K.; Roberts, D.; et al. BRAK/CXCL14 is a potent inhibitor of angiogenesis and a chemotactic factor for immature dendritic cells. Cancer Res. 2004, 64, 8262-8270. [CrossRef] [PubMed]

164. Hata, R.; Izukuri, K.; Kato, Y.; Sasaki, S.; Mukaida, N.; Maehata, Y.; Miyamoto, C.; Akasaka, T.; Yang, X.; Nagashima, Y.; et al. Suppressed rate of carcinogenesis and decreases in tumour volume and lung metastasis in CXCL14/BRAK transgenic mice. Sci. Rep. 2015, 5, 9083. [CrossRef]

165. Liu, Y.; Chang, Q.; Wu, X.; Yu, Y.; Zhang, H. Effect of chemokine CXCL14 on in vitro angiogenesis of human hepatocellular carcinoma cells. Arch. Physiol. Biochem. 2020, 1-7. [CrossRef]

166. Simson, L.; Ellyard, J.I.; Dent, L.A.; Matthaei, K.I.; Rothenberg, M.E.; Foster, P.S.; Smyth, M.J.; Parish, C.R. Regulation of carcinogenesis by IL-5 and CCL11: A potential role for eosinophils in tumor immune surveillance. J. Immunol. 2007, 178, 4222-4229. [CrossRef] 
167. Xing, Y.; Tian, Y.; Kurosawa, T.; Matsui, S.; Touma, M.; Yanai, T.; Wu, Q.; Sugimoto, K. CCL11-induced eosinophils inhibit the formation of blood vessels and cause tumor necrosis. Genes Cells 2016, 21, 624-638. [CrossRef]

168. Berenguer, J.; Lagerweij, T.; Zhao, X.W.; Dusoswa, S.; van der Stoop, P.; Westerman, B.; de Gooijer, M.C.; Zoetemelk, M.; Zomer, A.; Crommentuijn, M.H.W.; et al. Glycosylated extracellular vesicles released by glioblastoma cells are decorated by CCL18 allowing for cellular uptake via chemokine receptor CCR8. J. Extracell. Vesicles 2018, 7, 1446660. [CrossRef]

169. Sato, S.; Weaver, A.M. Extracellular vesicles: Important collaborators in cancer progression. Essays Biochem. 2018, 62, 149-163.

170. Omland, S.H.; Wettergren, E.E.; Mollerup, S.; Asplund, M.; Mourier, T.; Hansen, A.J.; Gniadecki, R. Cancer associated fibroblasts (CAFs) are activated in cutaneous basal cell carcinoma and in the peritumoural skin. BMC Cancer 2017, 17, 675. [CrossRef]

171. Gao, J.; Li, Z.H.; Tang, W.; Wu, Q.N.; Liu, G.H.; Zheng, W.B. Chemokine C-C motif ligand 18 expression correlates with tumor malignancy in breast cancer. Pathol. Biol. 2015, 63, 199-203. [CrossRef] [PubMed]

172. Nariţa, D.; Seclaman, E.; Ursoniu, S.; Ilina, R.; Cireap, N.; Anghel, A. Expression of CCL18 and interleukin-6 in the plasma of breast cancer patients as compared with benign tumor patients and healthy controls. Rom. J. Morphol. Embryol. 2011, 52, 1261-1267.

173. Sun, J.H.; Fan, N.; Zhang, Y. Correlation between serum level of chemokine (C-C motif) ligand 18 and poor prognosis in breast cancer. Genet. Mol. Res. 2016, 15. [CrossRef]

174. Wang, J.; Qin, Y.; Zhu, G.; Huang, D.; Wei, M.; Li, G.; She, L.; Zhang, D.; Wang, G.; Chen, X.; et al. High serum CCL18 predicts a poor prognosis in patients with laryngeal squamous cell carcinoma. J. Cancer 2019, 10, 6910-6914. [CrossRef] [PubMed]

175. Huang, H.; Li, J.; Hu, W.J.; Chen, C.; Luo, H.Q.; Tang, X.D.; Zhou, K.Y.; Zhong, W.T.; Li, X.Y. The serum level of CC chemokine ligand 18 correlates with the prognosis of non-small cell lung cancer. Int. J. Biol. Mark. 2019, 34, 156-162. [CrossRef]

176. Plönes, T.; Krohn, A.; Burger, M.; Veelken, H.; Passlick, B.; Müller-Quernheim, J.; Zissel, G. Serum level of CC-chemokine ligand 18 is increased in patients with non-small-cell lung cancer and correlates with survival time in adenocarcinomas. PLoS ONE 2012, 7, e41746. [CrossRef]

177. Yuan, L.; Wan, J.; Huang, C.; Liang, J.; Liu, M.; Yue, C.; Li, L. Evaluation of serum CCL18 as a potential biomarker for ovarian cancer. Cancer Biomark. 2017, 21, 97-104. [CrossRef] [PubMed]

178. Xu, Y.; Zhang, L.; Sun, S.K.; Zhang, X. CC chemokine ligand 18 and IGF-binding protein 6 as potential serum biomarkers for prostate cancer. Tohoku J. Exp. Med. 2014, 233, 25-31. [CrossRef]

179. Miyake, M.; Ross, S.; Lawton, A.; Chang, M.; Dai, Y.; Mengual, L.; Alcaraz, A.; Giacoia, E.G.; Goodison, S.; Rosser, C.J. Investigation of CCL18 and A1AT as potential urinary biomarkers for bladder cancer detection. BMC Urol. 2013, 13, 42. [CrossRef]

180. Schmid, S.; Le, U.T.; Haager, B.; Mayer, O.; Dietrich, I.; Elze, M.; Kemna, L.J.; Zissel, G.; Passlick, B. Local Concentrations of CC-Chemokine-Ligand 18 Correlate with Tumor Size in Non-small Cell Lung Cancer and Are Elevated in Lymph Node-positive Disease. Anticancer Res. 2016, 36, 4667-4671. [CrossRef]

181. Huang, H.; Li, J.; Hu, W.J.; Chen, M.H.; Chen, S.S.; Chen, C.; Luo, H.Q.; Zhou, K.Y.; Liu, X.G.; Li, X.Y. Positive expression of chemokine (C-C Motif) ligand 18 and prognosis in cancer: A meta-analysis. J. BUON 2018, 23, 1185-1194. [PubMed]

182. Mao, L.; Zhuang, R.; Qin, L.; Han, Z.; Huang, X.; Chen, R.; Su, Y.; Ge, L.; Yang, J.; Li, J.; et al. CCL18 overexpression predicts a worse prognosis in oral squamous cell carcinoma (OSCC). Neoplasma 2020, 67, 700-706. [CrossRef]

183. Schmid, S.; Csanadi, A.; Kozhuharov, N.; Tchudjin, M.; Kayser, C.; Rawluk, J.; Passlick, B.; Werner, M.; Prasse, A.; Kayser, G. CC-Chemokine Ligand 18 Is an Independent Prognostic Marker in Lymph Node-positive Non-small Cell Lung Cancer. Anticancer Res. 2018, 38, 3913-3918. [CrossRef] [PubMed]

184. Uhlén, M.; Fagerberg, L.; Hallström, B.M.; Lindskog, C.; Oksvold, P.; Mardinoglu, A.; Sivertsson, Å.; Kampf, C.; Sjöstedt, E.; Asplund, A.; et al. Proteomics. Tissue-based map of the human proteome. Science 2015, 347, 1260419. [CrossRef]

185. Uhlen, M.; Zhang, C.; Lee, S.; Sjöstedt, E.; Fagerberg, L.; Bidkhori, G.; Benfeitas, R.; Arif, M.; Liu, Z.; Edfors, F.; et al. A pathology atlas of the human cancer transcriptome. Science 2017, 357, eaan2507. [CrossRef] 
186. Pio, R.; Ajona, D.; Ortiz-Espinosa, S.; Mantovani, A.; Lambris, J.D. Complementing the Cancer-Immunity Cycle. Front. Immunol. 2019, 10, 774. [CrossRef]

187. Litviakov, N.; Tsyganov, M.; Larionova, I.; Ibragimova, M.; Deryusheva, I.; Kazantseva, P.; Slonimskaya, E.; Frolova, I.; Choinzonov, E.; Cherdyntseva, N.; et al. Expression of M2 macrophage markers YKL-39 and CCL18 in breast cancer is associated with the effect of neoadjuvant chemotherapy. Cancer Chemother. Pharmacol. 2018, 82, 99-109. [CrossRef]

Publisher's Note: MDPI stays neutral with regard to jurisdictional claims in published maps and institutional affiliations.

(C) 2020 by the authors. Licensee MDPI, Basel, Switzerland. This article is an open access article distributed under the terms and conditions of the Creative Commons Attribution (CC BY) license (http://creativecommons.org/licenses/by/4.0/). 